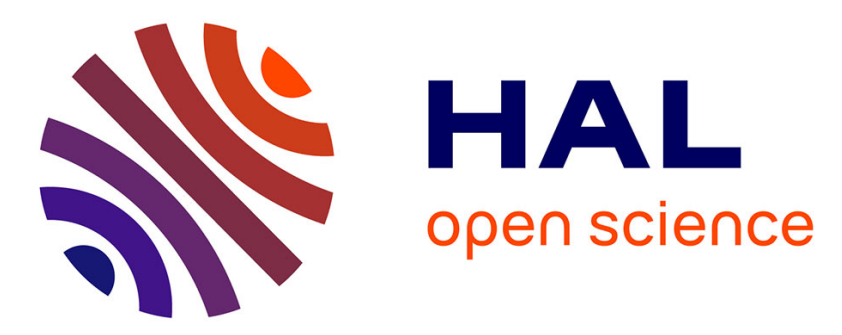

\title{
Simulation of spring snowmelt runoff by considering micro-topography and phase changes in soil layer
}

T. Nakayama, M. Watanabe

\section{To cite this version:}

T. Nakayama, M. Watanabe. Simulation of spring snowmelt runoff by considering micro-topography and phase changes in soil layer. Hydrology and Earth System Sciences Discussions, 2006, 3 (4), pp.2101-2144. hal-00298747

\section{HAL Id: hal-00298747 \\ https://hal.science/hal-00298747}

Submitted on 8 Aug 2006

HAL is a multi-disciplinary open access archive for the deposit and dissemination of scientific research documents, whether they are published or not. The documents may come from teaching and research institutions in France or abroad, or from public or private research centers.
L'archive ouverte pluridisciplinaire HAL, est destinée au dépôt et à la diffusion de documents scientifiques de niveau recherche, publiés ou non, émanant des établissements d'enseignement et de recherche français ou étrangers, des laboratoires publics ou privés. 
Hydrol. Earth Syst. Sci. Discuss., 3, 2101-2144, 2006 www.hydrol-earth-syst-sci-discuss.net/3/2101/2006/

(C) Author(s) 2006. This work is licensed under a Creative Commons License.
Hydrology and

Earth System

Sciences

Discussions

Papers published in Hydrology and Earth System Sciences Discussions are under open-access review for the journal Hydrology and Earth System Sciences

\section{Simulation of spring snowmelt runoff by considering micro-topography and phase changes in soil layer}

T. Nakayama ${ }^{1}$ and M. Watanabe ${ }^{2}$

${ }^{1}$ Asian Environmental Research Group, National Institute for Environmental Studies (NIES), 16-2 Onogawa, Tsukuba, Ibaraki 305-8506, Japan

${ }^{2}$ Faculty of Environmental Information, Keio University, 5522 Endo, Fujisawa, Kanagawa 252-8520, Japan

Received: 10 July 2006 - Accepted: 31 July 2006 - Published: 8 August 2006

Correspondence to: T. Nakayama (nakat@nies.go.jp)

\section{HESSD}

3, 2101-2144, 2006

Snowmelt runoff micro-topography and phase change

T. Nakayama and M. Watanabe

Title Page

Abstract Introduction

Conclusions References

Tables Figures

14 $>$ I

4

Back

Close

Full Screen / Esc

Printer-friendly Version

Interactive Discussion 


\section{Abstract}

The NICE model was extended to include the effect of the micro-topography in slope and shading characteristics and the phase changes in soil moisture on snow/frost depths and snowmelt runoff by combining the land-surface, the multi-layer runoff, and

5 the groundwater flow models (NICE-SNOW). The model was applied to the upstream regions of shrinking Kushiro Mire in the invasion of alder, where the spring runoff affects greatly the annual sediment and nutrient transports because the spring flood continues in longer time than that in typhoon seasons. The simulation reproduced excellently the observed values of annual river discharge including snowmelt runoff with the greater time-to-peak of runoff than in snow-free period, in addition to snow depth, frost depth, soil temperature, soil moisture, and groundwater level, by conducting the quantitative assessment of goodness-of-fit and parameter sensitivity analysis. We quantified that the mechanism of spring snowmelt runoff is related to changes in micro-topography, soil structure, soil temperature, soil moisture, and groundwater flow. The model shows discharge of catchment in the same way as some previous researches though they are very important as water resources of catchment. After the frozen soil restricts the infiltration in the coldest part of winter, the thawed soil increases the pore size in the early spring. The NICE-SNOW could explain the snowmelt flood continues a longer time than that in the typhoon period because some part of meltwater flows as an intermediate flow in the partially-thawed hillslope soil layer. This is also related to the simulation result that more than half of total soil moisture stays unfrozen at some places even in winter periods, which indicates that there is a high degree of spatial heterogeneity of frozen ground.
HESSD

3, 2101-2144, 2006

Snowmelt runoff micro-topography and phase change

T. Nakayama and M. Watanabe

Title Page

Abstract Introduction

Conclusions

Tables

References Figures

14

4

Back

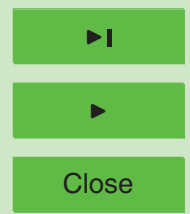

Full Screen / Esc

Printer-friendly Version

Interactive Discussion 


\section{Introduction}

The spring snowmelt runoff has a greater effect on the water balance in the northern region of Japan (Fig. 1) because the spring flood continues in longer time than that in typhoon seasons from August to October (Fig. 2). This runoff also affects sedi5 ment/nutrient transports and vegetation change in the downstream region (Ministry of Environment, 2002; Nakayama and Watanabe, 2004).

Previous studies of the frost/thaw process have firstly focused on the mechanism of granular structure formation through freezing and thawing of soil material by the observed fabrics of cross section view of core (Pawluk, 1988), the relationship be10 tween the infiltration, hydraulic conductivity, the snowmelt water equivalent, and the premelt soil moisture (Chamberlain and Gow, 1979; Benoit et al., 1988; Hayhoe et al., 1993), and the heat and water dynamics of the soil column by using one-dimensional model simulation such as SOIL (Lundin, 1990; Johnsson and Jansson, 1991), SHAW (Simultaneous Heat And Water) (Flerchinger and Saxton, 1989a, b), and SVAT (SoilVegetation-Atmosphere Transfer) (Stahli and Jansson, 1998). However, these studies are applied to the point scale and not applied to the catchment scale in the snowmelt period due to the difficulty of setting measurement systems, the complexities and variety of gathering data, and deviations from the original objectives of collecting the meteorological data.

20 Some researches by using remote sensing data such as NOAA-AVHRR (Advanced Very High Resolution Radiometer), RADARSAT, ERS-SAR (European Remote Sensing Satellite - Synthetic Aperture Radar), and Landsat TM data (Swamy and Brivio, 1997; Mitchell and DeWalle, 1998; Schaper et al., 1999; Nagler et al., 2000) and by using point measurements (Mamiya and Chiba, 1985; Sharratt et al., 1999) show that 25 the effect of micro-topography on snow depth and frost/thaw processes needs to be included to the physically based model in order to evaluate and forecast both qualitatively and quantitatively the spring snowmelt runoff, although some researches show the effect of localities of snow and frost depths on the runoff discharge disappears at
HESSD

$3,2101-2144,2006$

Snowmelt runoff micro-topography and phase change

T. Nakayama and M. Watanabe

Title Page

Abstract

Conclusions

Tables

References

Figures

14

4

Back

Full Screen / Esc

Printer-friendly Version

Interactive Discussion 
the downstream of catchment (Flerchinger and Saxton, 1989a, b; Lundin, 1990; Johnsson and Jansson, 1991; Hayhoe et al., 1993; Semadeni-Davies, 1997; Kennedy and Sharratt, 1998; Stahli and Jansson, 1998; Boggild et al., 1999; Shanley and Chalmers, 1999; Stahli et al., 2001).

5 Many models of snowmelt runoff have been developed around the world: SSARR (Streamflow Synthesis and Reservoir Regulation) (USACE, 1991), HEC (Hydrologic Engineering Center) (Hydrologic Engineering Center, 1997), NWSRFS (National Weather Service River Forecast System) (Anderson, 1968, 1973), PRMS (Precipitation Runoff Modelling System) (Leavesley et al., 1983), SRM (Snowmelt Runoff Model) 10 (Martinec and Rango, 1986), and GAWSER (Guelph All-Weather Storm-Event Runoff) (Ghate and Whitely, 1977). These semi-physical surface runoff models can predict generally well the spring peaks and recessions, but cannot evaluate quantitatively both the snow and frozen effects on spring runoff because of the dependence on various empirical relations (Semadeni-Davies, 1997). Some recent researches used the physically based model including the effects of topography on discharge generation both in large and small scales, for example, SAC (Burnash et al., 1973), Mosaic (Koster and Suarez, 1996), Noah (Ek et al., 2003), RHESSys (Regional Hydro-Ecologic Simulation System) (Hartman et al., 1999), and VIC (Variable Infiltration Capacity) (Liang et al., 1994; Cherkauer and Lettenmaier, 1999). Some researches show the predominance of snow effect (Shanley and Chalmers, 1999) and the importance of frozen effect (Stahli et al., 2001) in runoff response. These models simulate and evaluate the land surface and runoff processes, and the subsurface flow is only simulated by the water budget and there is no verification about the groundwater flow. By the way, the spring snowmelt runoff is closely related to the groundwater level change in addition to snow depth, soil temperature, and soil moisture (Daniel and Staricka, 2000; Nyberg et al., 2001), which is considered important around the Kushiro Mire of this study (Fig. 1). It is necessary to develop the process-based hydrology model, which includes snowmelt runoff process and local vegetation-surface-unsaturated-saturated water/heat process.

In this study, the process-based NICE (NIES Integrated Catchment-based Eco-

HESSD

$3,2101-2144,2006$

Snowmelt runoff micro-topography and phase change

T. Nakayama and M. Watanabe

Title Page

Abstract

Conclusions

Tables

Figures

14

4

Back

Full Screen / Esc

Printer-friendly Version

Interactive Discussion 
hydrology) model (Nakayama and Watanabe, 2004), which includes surfaceunsaturated-saturated water processes and assimilates land-surface processes describing the variation in phenology with MODIS (Moderate Resolution Imaging Spectroradiometer) satellite data, is extended to include the slope and shading characteristics 5 of microtopography and the phase change transitions in soil moisture (NICE-SNOW). We assessed the quantitative goodness-of-fit and parameter sensitivity in relation to changes in soil structure, soil temperature, soil moisture, groundwater level, and river discharge. We evaluated the effect of the snow layer and the frost/thaw soil layer on spring snowmelt runoff with much greater time-to-peak and slower decrease of dis10 charge, and carried out a long-term (annual) simulation not only at the snow-free periods but also at snowmelt periods in the upstream regions of shrinking Kushiro Mire in the invasion of alder (Fig. 1).

\section{Study area}

The Kushiro River catchment is located in Hokkaido, northern Japan, shown in Fig. 1. 15 The annual mean temperature is about $5-6^{\circ} \mathrm{C}$, making it one of the coldest regions in Japan. Mean annual precipitation is about $1100 \mathrm{~mm}$. In summer, the mean temperature is $17-19^{\circ} \mathrm{C}$, and fog is common. Recently, the water cycle has changed and drying phenomena has occurred in the Kushiro Mire, which is closely associated with vegetation change caused by the decrease of soil moisture and groundwater level, the inflow of increased sediment load from the surrounded areas due to river channelization, the conversion to urban or agricultural uses of surrounded area, and consequently the invasion of alder (Alnus japonica (Thunb.) Steud.) into the mire (Ministry of Environment, 2002; Nakayama and Watanabe, 2004). Though the mean temperature is about -5 to $-10^{\circ} \mathrm{C}$ and the precipitation is very small in winter, it is estimated that the snowmelt 25 runoff at the early spring seasons plays an important effect on these drying phenomena in addition to the river flood at the typhoon seasons (Fig. 2). The ground surface frozen during winter starts to melt in the early spring, which becomes greater water

HESSD

$3,2101-2144,2006$

Snowmelt runoff micro-topography and phase change

T. Nakayama and M. Watanabe

Title Page

Abstract Introduction

Conclusions

Tables

References

Figures

14

4

Back

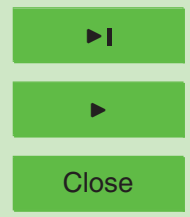

Full Screen / Esc

Printer-friendly Version

Interactive Discussion 
resources of catchment and influences the amount of runoff discharge. So, the spring surface runoff, which occurs when the ground is still partly frozen during the snowmelt period, can be a significant component of the water balance in Kushiro Mire, in addition to the typhoon flood. This spring runoff also affects greatly the annual sediment 5 and nutrient transports because the spring flood continues in longer time than that in typhoon seasons (Fig. 2), and consequently, occurs the change of mire vegetation in the downstream region of the catchment (Fig. 1). Because there are few studies about the process-based modeling including the slope and shading characteristics of microtopography and the phase-change transitions in soil moisture, it is very important to 10 evaluate the hydrologic process in the catchment in relation to the micro-processes of soil water.

\section{Model description of NICE-SNOW}

\subsection{NICE model}

Previously, we developed the NICE model, which includes surface-unsaturated15

saturated water processes and assimilates land-surface processes describing the variations of LAI (leaf area index) and FPAR (fraction of photosynthetically active radiation) from MODIS satellite data (Nakayama and Watanabe, 2004). These LAI and FPAR are important parameters for evaluating vegetation growth (Justice et al., 1998). The NICE model connects several sub-models from the ground to the surface by considering the water/heat fluxes, for example, (i) the gradient of hydraulic potentials between the deepest layer of unsaturated flow and the groundwater level, (ii) the effective precipitation calculated from the precipitation rate, the infiltration of precipitation into the upper soil moisture store, and the evapotranspiration rates, and (iii) the seepage between river and groundwater (Appendix A: Eqs. A1-A17, Fig. 3).

HESSD

3, 2101-2144, 2006

Snowmelt runoff micro-topography and phase change

T. Nakayama and M. Watanabe

Title Page

Abstract Introduction

Conclusions

Tables References Figures

14

4

Back

Close

Full Screen / Esc

Printer-friendly Version

Interactive Discussion 
3.2 Effect of micro-topography and meteorology on snow and frost depth

NICE model can simulate the snow process and soil temperatures in three unsaturated layers by using a full energy balance only in a flat plain (Nakayama and Watanabe, 2004). But it is difficult to simulate the local snow/frost depths and the phase changes 5 in the soil. In order to simulate the local snow/frost depths, it is necessary to calculate the downward radiation perpendicular to the ground surface from the total solar radiation including the effect of solar angle and ground-slope angle because the microtopography and meteorology affect greatly the local snow/frost depths (Fig. 3). Total solar radiation perpendicular to the ground surface, $W_{b}\left(\mathrm{~W} / \mathrm{m}^{2}\right)$, can be adjusted by the observed total solar radiation, $W_{a}\left(\mathrm{~W} / \mathrm{m}^{2}\right)$ :

$W_{b}=W_{a}\left[\cos \omega \cos \theta+\sin \omega \sin \theta \cos \left(\gamma_{a}-\lambda\right)\right]$

$\cos \omega=\sin \phi \sin \delta+\cos \phi \cos \delta \cosh _{a}$

$\sin \gamma_{a}=\frac{\cos \delta \sin h_{a}}{\sin \omega}$

where $\omega$ is the solar zenith angle, $\theta$ is the slope angle, $\gamma_{a}$ is the solar azimuthal angle, $15 \lambda$ is the slope azimuthal angle, $h_{a}$ (rad) is the hour angle, $\phi$ is the latitude ("+" means north and "-" means south), and $\delta$ is the solar declination. The value of $\delta$ can be empirically approximated as in Eqs. (4) and (5):

$\delta=\sin ^{-1}(0.398 \times \sin c)$

$c=4.841+\eta+0.033 \sin \eta$

$\eta=\left(\frac{2 \pi}{365}\right) /$

where I is the day of the year. The solar radiation on the south slope becomes much greater and the value on the northern slope decreases and approaches zero as the
HESSD

3, 2101-2144, 2006

Snowmelt runoff micro-topography and phase change

T. Nakayama and M. Watanabe

Title Page

Abstract Introduction

Conclusions References

Tables Figures

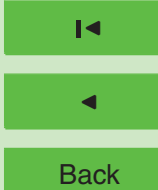

$\rightarrow$

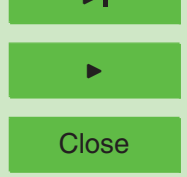

Full Screen / Esc

Printer-friendly Version

Interactive Discussion 
slope angle increases. Furthermore, the frost and thaw depths in the soil were evaluated by the phase change simulation and the Stefan solution as written in detail in the Sects. 3.3 and 3.4 .

\subsection{Modeling of phase changes in unsaturated layer}

5 During the winter season, the depth of frost/thaw layer change temporarily depending on the frost/thaw processes of soil structure (Daniel and Staricka, 2000). In the coldest part of winter, the infiltration rate is greatly reduced in the freezing layer because the water in the soil pores freezes, filling them with ice as the soil frost layer develops. The NICE-SNOW extends the original NICE model (Appendix A) by the partial differentiation of the left sides of the Eqs. (A6-A8), and calculates the phase changes of ice and liquid fractions of soil moisture (Fig. 3);

$\frac{\partial \theta_{l, 1}}{\partial t}+\frac{\rho_{i}}{\rho_{l}} \frac{\partial \theta_{i, 1}}{\partial t}=\frac{1}{D_{1}}\left[P_{w 1}-q_{1,2}-\frac{1}{\rho_{l}} E_{g s}\right]$

$\frac{\partial \theta_{l, 2}}{\partial t}+\frac{\rho_{i}}{\rho_{l}} \frac{\partial \theta_{i, 2}}{\partial t}=\frac{1}{D_{2}}\left[q_{1,2}-q_{2,3}-\frac{1}{\rho_{l}} E_{c t}\right]$

$\frac{\partial \theta_{l, 3}}{\partial t}+\frac{\rho_{i}}{\rho_{l}} \frac{\partial \theta_{i, 3}}{\partial t}=\frac{1}{D_{3}}\left[q_{2,3}-q_{3}\right]$

$15 \theta_{l, j}\left(\mathrm{~m}^{3} / \mathrm{m}^{3}\right)$ and $\theta_{i, j}\left(\mathrm{~m}^{3} / \mathrm{m}^{3}\right)(\mathrm{j}=1,2,3)$ are the liquid water content and the ice content of each soil layer; $\rho_{I}(\mathrm{~kg} / \mathrm{m} 3)$ and $\rho_{i}(\mathrm{~kg} / \mathrm{m} 3)$ are densities of the liquid water and the ice, respectively. Furthermore, the fraction of unfrozen water is calculated by the following equation (Flerchinger and Saxton, 1989a, b; Cherkauer and Lettenmaier, 1999):

$\theta_{l}=\theta_{s}\left[\frac{\frac{L_{f} T}{T+273.16}+c R(T+273.16)}{g \psi_{s}}\right]^{-\frac{1}{B}}$
HESSD

3, 2101-2144, 2006

Snowmelt runoff micro-topography and phase change

T. Nakayama and M. Watanabe

Title Page

Abstract Introduction

Conclusions References

Tables Figures

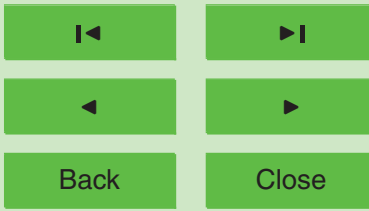

Full Screen / Esc

Printer-friendly Version

Interactive Discussion 
$\psi_{s}(\mathrm{~m})$ is the soil matric potential at saturation; $\theta_{s}\left(\mathrm{~m}^{3} / \mathrm{m}^{3}\right)$ is the value of $\theta$ at saturation; $L_{f}(\mathrm{~J} / \mathrm{kg})$ is the latent heat of fusion; $T(\mathrm{C})$ is the soil temperature; $B$ is the empirical constant; $c$ (moles $/ \mathrm{kg}$ ) is the solute concentration in the soil solution $(=0) ; R$ is the universal gas constant $(=8.3143 \mathrm{~J} / \mathrm{mole} / \mathrm{K})$. The above Eqs. $(7-10)$ include the 5 phase changes in the unsaturated layer, and can simulate the penetration of the frost front in the Sect. 3.4. These processes also include the vertical and temporal changes of hydraulic conductivity during the winter season, which finally returns to the original value in snow-free period.

\subsection{Estimation of frost and thaw depth by the Stefan solution}

10 The Stefan solution provides a useful method for predicting the frost depth $Z$ in soils:

$Z=\beta \sqrt{F}$,

where $\beta$ is an empirical constant, and $F$ is a time-temperature integral usually calculated by summing mean daily temperatures below $0^{\circ} \mathrm{C}$. Though the Eq. (11) is very useful where little site-specific information is available (Nelson et al., 1997), only the peak value of the frost depth can be calculated and the effect of micro-topography on the frost depth depends on the value of coefficient $\beta$.

In the NICE-SNOW, the frost and thaw depth is defined in a similar equation to the approximation of the Stefan solution by the following (The Institute of Geocryology, 1974):

${ }_{20} \xi_{f}=\sqrt{\frac{2 \kappa_{f} \tau_{h} \sum_{i=1}^{t}\left(T_{f}-T_{g}\right)}{L_{f} \rho_{l} \theta}}$
HESSD

3, 2101-2144, 2006

Snowmelt runoff micro-topography and phase change

T. Nakayama and M. Watanabe

Title Page

Abstract Introduction

Conclusions References

Tables Figures

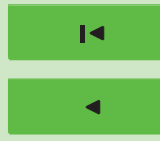

$\rightarrow$ I

Back

Close

Full Screen / Esc

Printer-friendly Version

Interactive Discussion 
$\xi_{t}=\sqrt{\frac{2 \kappa_{t} \tau_{h} \sum_{i=1}^{t}\left(T_{g}-T_{f}\right)}{L_{f} \rho_{i} \theta}}$

HESSD

3, 2101-2144, 2006

$\kappa_{f}$ and $\kappa_{t}(\mathrm{~W} / \mathrm{m} / \mathrm{K})$ are the thermal conductivity of frost and thawed soils; $\tau_{h}(\mathrm{~s})$ is the time length; $T_{f}(\mathrm{~K})$ is the freezing point of water.

3.5 Two-layer surface runoff model including frost/thaw processes

5 We suppose that the soil A-layer (Takasao and Shiiba, 1980) is divided into two layers during the winter season (Fig. 3): the frost/thaw processes do not affect the deeper layer in winter, and the upper layer is temporarily changed. We call the deeper layer an " $\mathrm{A}_{0}$-layer", and the upper layer an " $\mathrm{A}_{1}$-layer". So, the kinematic wave model for surface runoff with one layer in the Eqs. (A11) and (A12) can be extended into the following 10 two-layer model:

$\frac{\partial h}{\partial t}+\frac{1}{b(x)} \frac{\partial}{\partial x}\{q b(x)\}=r^{\prime}(x, t) \cos \theta(x)$

$q=\frac{k_{0} \sin \theta(x)}{\gamma_{0}} h, \quad\left(0<h<d_{0}\right)$

$q=\frac{k_{1} \sin \theta(x)}{\gamma_{1}}\left(h-d_{0}\right)+\frac{k_{0} \sin \theta(x)}{\gamma_{0}} h, \quad\left(d_{0} \leq h \leq d_{0}+d_{1}\right)$

$q=\frac{\sqrt{\sin \theta(x)}}{n}\left(h-d_{0}-d_{1}\right)^{m}+\frac{k_{1} \sin \theta(x)}{\gamma_{1}}\left(h-d_{0}\right)+\frac{k_{0} \sin \theta(x)}{\gamma_{0}} h,\left(h \geq d_{0}+d_{1}\right)$

15 where $q\left(\mathrm{~m}^{2} / \mathrm{s}\right)$ is the discharge of unit width; $r^{\prime}(x, t)(\mathrm{m} / \mathrm{s})$ is the effective rainfall intensity including the snowmelt volume at position $x$ and time $t ; b(x)(\mathrm{m})$ is the width of the

Snowmelt runoff micro-topography and phase change

T. Nakayama and M. Watanabe

Title Page

Abstract Introduction

Conclusions References

Tables

Figures

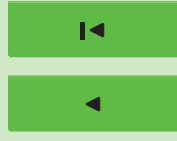

$\rightarrow$

Back

Close

Full Screen / Esc

Printer-friendly Version

Interactive Discussion 
flow; $\theta(x)$ is the riverbed gradient; $k(\mathrm{~m} / \mathrm{s})$ is the hydraulic conductivity in the A-layer with a depth of $D(\mathrm{~m})$ near the ground surface; $n(\mathrm{~m}-\mathrm{s})$ is the Manning coefficient; and $m=5 / 3$. When $H(\mathrm{~m})$ is defined as the depth of the rainwater flow in the A-layer, $h(\mathrm{~m})$ as the apparent flow depth $(=\gamma H), \gamma$ as the porosity of the A-layer and $d=\gamma D$. When 5 the subscripts 0 and 1 are defined as the values at the $A_{0}$-layer and the $A_{1}$-layer respectively, the hydraulic conductivity $k$ and the porosity $\gamma$ gre $\left(k_{0}, \gamma_{0}\right)$ at the $A_{0}$-layer and $\left(k_{1}, \gamma_{1}\right)$ at the $A_{1}$-layer, and then $d_{0}=(1-\alpha) \gamma_{0} D, d_{1}=\alpha \gamma_{1} D . \alpha$ is the depth ratio of the $A_{1}$-layer to the A-layer, and can be determined from the simulation result of phase changes as written in the above Sect. 3.3 and 3.4.

The hydraulic conductivity in the frozen layer is calculated in the following (Lundin, 1990; Johnsson and Lundin, 1991; Stahli et al., 1999):

$k_{f}=10^{-E i \cdot \varepsilon} k$,

where $k_{f}$ is the hydraulic conductivity of frost soil, $\varepsilon$ is the thermal quality, $E_{i}$ is the impedance parameter, and $k$ is the hydraulic conductivity in the unfrozen layer. In the spring snowmelt period, the frost/thaw processes increase the soil porosity and hydraulic conductivity (Benoit et al., 1988; Pawluk, 1988). So, we supposed that the hydraulic conductivity increases temporarily in the thawing layer due to the macropores and desiccation cracks of the soil in the previous research at the end of winter (Chamberlain and Gow, 1979; Benoit et al., 1988).

\section{Input data and boundary conditions for simulation}

\subsection{Measurements for validation}

The investigation for model validation was conducted in the Kushiro River catchment. We set meteorological stations at 3 points (mire, grassland, and forest), groundwater level meters at 30 points, and flow depth meters at 13 points around the Kushiro River catchment (Table 1). Measurements were made for two years from 1 January 2001 to
HESSD

3, 2101-2144, 2006

Snowmelt runoff micro-topography and phase change

T. Nakayama and M. Watanabe

\section{Title Page}

Abstract Introduction

Conclusions

Tables References Figures

14

4

Back

Close

Full Screen / Esc

Printer-friendly Version

Interactive Discussion

EGU 
31 December 2002. Meteorological variables were automatically recorded every hour at each station on a computer. The variables were air temperature (Kona-System, KDC-S2), humidity (Kona-System, KDC-S2), wind speed (Makino-Keiki, AC750), net radiation (Eikou-Seiki, CN-11), albedo (Eikou-Seiki, MR-22), precipitation (Ikeda-Keiki, $5 \mathrm{RH}-5$ ), soil temperature (Chino, platinum), soil moisture (Delta-T, ML2x, and PR1/6), and groundwater level (Kona-System, Kadec-Mizu-II). Furthermore, snow depth was measured every one-two weeks by using snow depth meters during winter and spring. At the same time, frozen tubes were used to measure and monitor the extent of the frost soil layer. Details are described in Nakayama and Watanabe (2004). Furthermore, the 10 snow depth data at Tomakomai $\left(42^{\circ} 37^{\prime} 24^{\prime} \mathrm{N}, 141^{\circ} 35^{\prime} 06^{\prime \prime} \mathrm{E}\right.$, mean elevation $\left.6 \mathrm{~m}\right)$ and Noboribetsu $\left(42^{\circ} 27^{\prime} 24^{\prime \prime} \mathrm{N}, 141^{\circ} 07^{\prime} 18^{\prime \prime} \mathrm{E}\right.$, mean elevation $197 \mathrm{~m}$; see Fig. 1) outside the Kushiro River catchment in Hokkaido and the frost depth data at Noboribetsu from 1 January 1984 to 31 December 1985 (Mamiya and Chiba, 1985) were used in order to evaluate the effect of micro-topography, local meteorology and land cover on the 15 snow and frost depths (Fig. 1). The forcing meteorology data for 1984-1985 were the AMeDAS data in the same as the simulation for 2001-2002.

In Fig. 1, red line is border of study area for snowmelt runoff simulation at Kucyoro River catchment (area: $123 \mathrm{~km}^{2}$ ), a tributary of the Kushiro River. The Kucyoro River consists of 13 tributaries. The changes in groundwater level at 5 points and river discharge at one point were measured during the same periods as the meteorological observations (G-1 to G-5 and R-5 in Table 1). The water level (KADEC, MIZU-II) was automatically recorded to data-loggers at hourly intervals. During winter, when the water level meters were not set up, river discharge data (supplied by the Kushiro Development and Construction Department, Hokkaido Regional Development Bureau, near R-5 in Table 1) at one point were used as the observed data. There are no observed data of groundwater level in winter because it is difficult to set up the equipments.

HESSD

$3,2101-2144,2006$

Snowmelt runoff micro-topography and phase change

T. Nakayama and M. Watanabe

Title Page

Abstract

Conclusions

Tables

References

Figures

14

4

Back

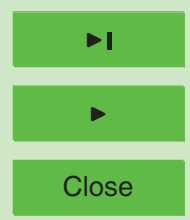

Full Screen / Esc

Printer-friendly Version

Interactive Discussion 
The NICE-SNOW was driven with hourly meteorological data of the following variables: downward short- and long-wave radiation, precipitation, temperature, wind speed, humidity, and dew-point temperature. These variables were measured at three meteoro5 logical stations (A-1 to -3 in Table 1 ), and were obtained at 11 points from AMeDAS (Automated Meteorological Data Acquisition System) data in the Japan Meteorological Business Support Center (M-1 to -11 in Table 1). Because the model is used in a distributed manner and the forcing data need to be determined for each $500 \mathrm{~m}$ grid, the weighting of the data points in inverse proportion to the distance was back-calculated in each grid. Furthermore, the downward radiation perpendicular to the ground surface was calculated from the total solar radiation by the Eq. (1) in order to include the effect of solar angle and ground-slope angle because the micro-topography and meteorology affect greatly the local snow/frost depths.

Mean elevation data, Soil texture data, and Vegetation class data were converted 15 and inputted into the NICE-SNOW with a resolution of $500 \mathrm{~m}$. The vertical dimension was divided into 20 layers with a weighting factor of 1.1 (finer at the upper layers). The upper layer was set at $2 \mathrm{~m}$ depth, and the 20th layer was defined as an elevation of $-250 \mathrm{~m}$ from the sea surface. Geological structure was divided into four types on the basis of hydraulic conductivity $\left(K_{h}\right.$ and $\left.K_{v}\right)$, the specific storage of porous material $20\left(S_{S}\right)$, and specific yield $\left(S_{y}\right)$ by using soil samples taken at two depths $(0.1$ and $1.0 \mathrm{~m})$ and previous research about 150 sample data points (Ohara et al., 1975). Vegetation class and soil texture was used to calculate about 50 vegetation and soil parameters include vegetation cover, green fraction, albedo, surface roughness length and zero displacement height, soil conductivity and soil water potential at saturation, and some 25 parameters of stomatal resistance that relate to environmental factors. The thickness of A-layer $(d)$ was set at $20 \mathrm{~cm}$ from the ground surface by considering the borehole data of our previous research (Nakayama and Watanabe, 2004) and previous data from the Geological Survey of Hokkaido (Ohara et al., 1975), which includes some grass roots

Snowmelt runoff micro-topography and phase change

T. Nakayama and M. Watanabe

\section{Title Page}

Abstract

Conclusions

Tables

14

4

Back

Introduction

References

Figures

$\rightarrow$

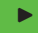

Close

Full Screen / Esc

Printer-friendly Version

Interactive Discussion 
in the upper level and consists mainly of silt and ash deposits in the deeper levels. Details are written in Nakayama and Watanabe (2004).

About the upstream boundaries, reflecting condition on hydraulic head was used supposing that there is no inflow from the mountains in the opposite direction. The 5 hydraulic head values parallel to the ground level were inputted as the initial condition for the groundwater flow model. For the model simulating hillslope hydrology, the flow depth and the discharge at the uppermost ridges of the mountains were set as zero throughout the simulation. In river cells, outflows from the riverbeds of $-1 \mathrm{~m}$ mean elevation from the ground surface were considered. The riverbed hydraulic conductance was set at $k_{r}=300 \mathrm{~m}^{2} / \mathrm{h}$ (Nakayama and Watanabe, 2004).

\subsection{MODIS data}

Two vegetation characteristics, LAI and FPAR $\left(\mu \mathrm{mol} / \mathrm{m}^{2} / \mathrm{s}\right)$ values of MODIS data, were inputted to the NICE-SNOW every 8 days in order to include seasonal variations of vegetation phenology. The methods how to calculate both values from digital numbers of MODIS data and how to input these values to the NICE-SNOW are written in Nakayama and Watanabe (2004). The seasonal variations in MODIS LAI and FPAR $\left(\mu \mathrm{mol} / \mathrm{m}^{2} / \mathrm{s}\right)$ images of the Kushiro River Catchment in the entire $2001(1-\mathrm{km}$ mesh; image areas: $\left.43^{\circ} 00-45^{\prime} \mathrm{N}, 144^{\circ} 00-45^{\prime} \mathrm{E}\right)$ are displayed with vertical scale showing the units (Figs. $4 a-b$ ). In these figures, the blue line is the border of the catchment, and the pink line is that of Kushiro Mire. From these figures, it can be seen that LAI and FPAR change seasonally, particularly in the mire, implying that the vegetation phenology and the water cycle are closely related in the mire. Both parameters take their maximum values (green) from early summer to fall when vegetation is growing, and their minimum in winter, and both variables are highly correlated $\left(R_{r}=0.891\right)$. In winter, both parameters are almost zero in the lower elevation areas because the snow mostly covers the comparatively shorter vegetations.

HESSD

3, 2101-2144, 2006

Snowmelt runoff micro-topography and phase change

T. Nakayama and M. Watanabe

Title Page

Abstract

Conclusions

Tables

References

Figures

14

4

Back

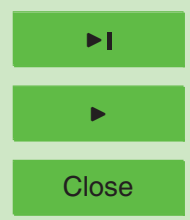

Full Screen / Esc

Printer-friendly Version

Interactive Discussion 
The simulation area is $50 \mathrm{~km}$ wide by $80 \mathrm{~km}$ long with a grid spacing of $500 \mathrm{~m}$, covering the whole Kushiro River catchment (Fig. 1). The simulation was conducted on an NEC SX-6 supercomputer from 1 January 2001 to 31 December 2002 by using the interpo-

5 lated forcing data at each grid from the observed data and the AMeDAS data (Table 1). Only kinematic wave theory was applied to the stream network at the Kucyoro River (13 tributaries) (Fig. 1) because dynamic wave effect is small in this river despite the lower bed gradient (Fig. 11a in Nakayama and Watanabe, 2004). The time-step in the stream network model was changed from $\Delta t=8$ to $30 \mathrm{~s}$ in order to facilitate numerical stability. 10 Furthermore, one-dimensional simulation at Tomakomai and Noboribetsu outside the catchment was conducted from 1 January 1984 to 31 December 1985 (Mamiya and Chiba, 1985) by using the AMeDAS data in order to validate the snow and frost depth. In particular, the phase changes and the frozen/thaw front are calculated as follows; Firstly, three soil layers in unsaturated zone are subdivided into frost and thaw layers after determining the position of the frozen/thaw front. Secondly, the water/heat balance equations are solved by considering the phase changes. Thirdly, the hydraulic conductivity is updated by considering the effect of frost/thaw layer. Finally, the soil thermal properties for the next time step are calculated by the updated ice and liquid water contents.

\section{Results}

5.1 Effect of micro-topography and land cover on snow depth and soil frost

The simulation values of snow depth were compared with detailed experimental data at Hokkaido (Figs. 5a-b). Furthermore, the correlation between observed value and simulated value $r^{2}$ when the slope of regression line equals to 1 was also plotted. Fig.

Snowmelt runoff micro-topography and phase change

T. Nakayama and M. Watanabe

Title Page

Abstract

Conclusions

Tables

References Figures

14

4

Back

Close

Full Screen / Esc

Printer-friendly Version

Interactive Discussion 
uary 1984 to 31 December 1985, plotted with the observed value (Mamiya and Chiba, 1985). The snow depth at Noboribetsu was much greater than that at Tomakomai, because of the micro-topography and weather conditions, in particular, mean elevation. The simulation reproduces well the observed values at both places $\left(r_{\text {Nobo }}^{2}=0.556\right.$,

$5 \quad r_{\text {Toma }}^{2}=0.727$ ). Effect of different land covers (mire, grassland, and forest; A-1 to -3 in Table 1, Tsurui; M-5 in Table 1) on snow depth from 1 January 2001 to 30 April 2002 in Kushiro River catchment was evaluated (Fig. 5b). The correlation values in mire and forest $\left(r_{A-1}^{2}=0.605, r_{A-3}^{2}=0.544\right)$ are smaller than those in grassland and Tsurui observation point $\left(r_{A-2}^{2}=0.846, r_{M-5}^{2}=0.815\right)$. The NICE-SNOW cannot simulate correctly 10 the snow depth affected by the almost saturated groundwater in mire, which is also correlated with the overestimates of soil temperature written in the following Sect. 5.3. The snow depth in forest is affected by the locality of various trees, which can be reproduced better by using a finer model raster around the canopy and inputting a more correct meteorological data. The snow depth in grassland is largest and in mire small15 est, which can be reproduced well by the simulation.

The simulation results of frost depth by using the NICE-SNOW at Noboribetsu were plotted with the values observed by Mamiya and Chiba (1985), together with the correlation value $r^{2}$ (Fig. 6). The coefficient $\beta$ evaluated by the Eq. (11) is also plotted in this figure. Although previous research in Hokkaido suggested that the frost penetration is almost zero at a snow depth greater than $20 \mathrm{~cm}$ owing to the insulation effect of the snow preventing soil cooling (Ishikawa and Suzuki, 1964), the frost penetration progresses at a greater snow depth in this figure, which implies that various topographical and meteorological characteristics besides snow depth also affect frost depth. Furthermore, $\beta$ takes different values depending mainly on the slope direction, which suggests that the original Stefan solution in the Eq. (11) does not include physically the effect of slope direction and can't reproduce the effect of micro-topography. This is because the Stefan solution regards the air temperature as being the same as the ground-surface temperature. The frost depth simulated by the NICE-SNOW in the Eq. (12) agrees well with the observed value on both northern and southern slopes

HESSD

3, 2101-2144, 2006

Snowmelt runoff micro-topography and phase change

T. Nakayama and M. Watanabe

Title Page

Abstract Introduction

Conclusions

Tables

References

Figures

14

4

Back

Full Screen / Esc

Printer-friendly Version

Interactive Discussion 
$\left(r_{\text {North }}^{2}=0.833, r_{\text {South }}^{2}=0.732\right)$, and the NICE-SNOW can reproduce the frost depth on the northern slope is larger. This means that the NICE-SNOW correctly simulates the heat budget dependent on the slope and shading characteristics, and that the amount of sunshine falling on the slope is a major factor in the local difference of frost depth.

$5 \quad 5.2$ Soil moisture and groundwater with phase changes

The observed soil moisture data were compared with the simulated results in grassland and forest from 1 January 2001 to 31 December 2002 for two years, together with the precipitation distribution in the same period (Fig. 7; A-2 and -3 in Table 1). Soil moisture is not always recorded in the coldest period, because the measuring systems are vulnerable to the severe weather. The soil moisture takes greater values both in early spring (snowmelt) and fall (typhoon). The surface soil moisture in forest is higher than that in grassland, which indicates that the forest landcover retains more water in soil and vegetation than grassland does, and that grassland tends to quickly lose infiltrated water to the groundwater system and evapotranspiration. Furthermore, Watanabe, 2004). Generally, the simulated soil moistures reproduce excellently the observed values during two years. In winter periods, in particular, some of the soil water is frozen and the simulated liquid water agrees well the observed value, which indicates that the NICE-SNOW can simulate correctly the phase changes between the ice and the liquid.

The soil temperature quantified this phenomenon, and the NICE-SNOW reproduced excellently the observed soil temperature (Table 2). Some parts of the ground are frozen until mid March, and the snow does not melt except when the temperature temporarily becomes much greater than $0^{\circ} \mathrm{C}$. Then, around mid March, the temperature is about $0-2^{\circ} \mathrm{C}$, which is the phase-change temperature between snowfall and rainfall. At that time, the simulated surface soil temperature at a depth of $10 \mathrm{~cm}$ is about $0^{\circ} \mathrm{C}$, and the thawing process starts to move down. From late March to early April, the
HESSD

$3,2101-2144,2006$

Snowmelt runoff micro-topography and phase change

T. Nakayama and M. Watanabe

Title Page

Abstract

Conclusions

Tables

References

Figures

14

4

Back

Full Screen / Esc

Printer-friendly Version

Interactive Discussion 
deeper soil temperature rises to $0^{\circ} \mathrm{C}$. Theoretically, most of the frozen soil has melted by this time. In reality, there are a lot of macropores, large fractures, and roots in the soil, and various vegetations on the ground, where the deeper layer remains frozen longer in some places because they form an insulating layer (Nyberg et al., 2001). 5 Though the simulated values at the depth of $10 \mathrm{~cm}$ fluctuate more than the observed values due to the daily cycle of temperature fluctuations, the daily-averaged values agree well with the observed values $\left(r_{A-2,10}^{2}=0.876, r_{A-3,10}^{2}=0.789, r_{A-1,10}^{2}=0.804\right)$. The simulated values at the depth of $30 \mathrm{~cm}$ in grassland and forest reproduce excellently the observed values in this period $\left(r_{A-2,30}^{2}=0.958, r_{A-3,30}^{2}=0.974\right)$. The simulated data 10 at the depth of $30 \mathrm{~cm}$ in mire overestimates the observed data because the NICESNOW simulates only the soil temperature $\left(r_{A-1,30}^{2}=0.834\right)$. In mire, there is shallow and almost saturated snowmelt water with comparatively colder at the early spring, and therefore, the soil temperature at mire is lowest. It is necessary to include both soil and water effect in order to simulate the soil temperature in mire. Furthermore, 15 the soil moisture increases till late March owing to the temporary increase in hydraulic conductivity, enhancing the infiltration of meltwater into the ground after the frost layer thaws (Daniel and Staricka, 2000), and then gradually decreases until late spring. The increase in soil moisture till late March is also affected by the accumulation of water in frost soil through the upward movement of water from deeper unfrozen soil (Benoit et

l., 1988). When soil moisture reaches a maximum, the value is almost constant from the ground surface to the deeper layers, and the frozen soil layer is almost melted. After this period, meltwater transports silt and clay particles and plugs the newly created voids, consequently returning the soil to a state near the original hydraulic conductivity (Schuh, 1990).

25 The temporal variations in groundwater fluctuations are also quantitatively assessed (Table 2). The groundwater is affected by snowmelt water in the early spring season and flood in the typhoon season in the same way as soil moisture (Fig. 7). Generally speaking, the value takes a rapid increase at typhoon and a gradual decrease until the next typhoon period. The simulation values agree excellently with the measured
HESSD

3, 2101-2144, 2006

Snowmelt runoff micro-topography and phase change

T. Nakayama and M. Watanabe

Title Page

Abstract

Conclusions

Tables

Figures

14

4

Back

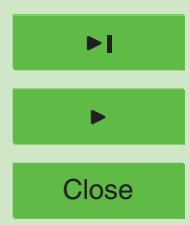

Full Screen / Esc

Printer-friendly Version

Interactive Discussion 
values all through the two years depending on precipitation and micro-topography both in the mountainous areas $\left(r_{G-13}^{2}=0.649\right)$, around the mire $\left(r_{G-23}^{2}=0.719\right)$ and in the mire $\left(r_{G-29}^{2}=0.408\right)$, because the NICE-SNOW includes a three-dimensional groundwater model and simulates the recharge rate in the upper layer and the seepage between 5 river and groundwater. In the mire (G-29), the groundwater level is almost constant from spring to the typhoons in the same way as soil moisture, which shows the high soil water capacity in the mire and that the groundwater acts as a long-term reservoir storing excessive soil water (Nakayama and Watanabe, 2004).

\subsection{Surface runoff process including snowmelt period}

10 The simulated river discharges are compared with observed values at a point in the Kucyoro River catchment (R-5 in Table 1$)$ together with the precipitation and the temperature at the Tsurui AMeDAS observation point (M-5 in Table 1) (Fig. 8). In this figure, the correlation between observed value and simulated value $r^{2}$ when the slope of regression line equals to 1 and Nash-Sutcliffe Criterion NS (Nash and Sutcliffe, 1970) 15 were also plotted. The observed precipitation includes both rain and snow by using the heater in the measurements of precipitation in winter. Total precipitation was $311 \mathrm{~mm}$, and the maximum precipitation intensity was $12 \mathrm{~mm} / \mathrm{hr}$ during this period. Temperature takes $0{ }^{\circ} \mathrm{C}$ from the middle March to the early April when the river discharge increases due to the snowmelt runoff. In the case that the simulation does not include the effects of snow or frost depth (Fig. 8b), constant values of the parameters in Eqs. (14) and (15) were used in the simulation (thickness of A-layer, $d=\gamma D=20 \mathrm{~cm}$; hydraulic conductivity, $k=0.02 \mathrm{~m} / \mathrm{s}$; effective porosity, $\gamma=0.2$; and Manning coefficient, $n=0.5 \mathrm{~m}-\mathrm{s}$ ) and the thickness of snow depth and $A_{1}$-layer was set at zero. The simulated value agrees well with the observed value after mid May, which implies that the original NICE model reproduces well the discharge in the snow-free period (Nakayama and Watanabe, 2004). However, from March to May, the simulated value does not agree with the observed value. It overestimates the observed value before early March, but underestimates it

HESSD

3, 2101-2144, 2006

Snowmelt runoff micro-topography and phase change

T. Nakayama and M. Watanabe

Title Page

Abstract Introduction

Conclusions

Tables

References

Figures

14

4

Back

Full Screen / Esc

Printer-friendly Version

Interactive Discussion 
from late March to late May, in particular, in April $\left(r^{2}=0.131, N S=-0.308\right)$.

The simulated discharge including the infiltration of precipitation into the snow layer and the snowmelt volume reproduces better the observed value (Fig. 8c). For the calculation of snow volume, we set the effective porosity of the snow at 0.7 because 5 the value generally takes a value of 0.4 to 0.9 . Before early March, the simulated value becomes smaller than that in Fig. $8 \mathrm{~b}$ and agrees better with the observed value, because the snow depth increases and the precipitation infiltrates the snow layer in this period. In the snowmelt period, the simulated value is improved by adding the snowmelt volume though the simulated value has a smaller time-to-peak and a larger peak value 10 a little than the observed value $\left(r^{2}=0.684, N S=0.236\right)$. This indicates that the snow layer causes a much greater time-to-peak of discharge than the discharge in snow-free period (Shanley and Chalmers, 1999), and that the NICE-SNOW can reproduce this swell of long wavelength of hydrograph characteristic of spring snowmelt runoff.

Figs. $8 d-f$ show the simulated discharge including the frost/thaw processes of soil 15 layer in the snowmelt period. The hydraulic conductivity and the effective porosity for freezing soil were calculated as $k_{1}=10^{-3} \mathrm{k}=2.0 \times 10^{-5} \mathrm{~m} / \mathrm{s}$ and $\gamma_{1}=0.02$, by substituting $\varepsilon=1$ and $E_{i}=3$ in Eq. (16) (Lundin, 1990; Stahli et al., 1999) (Fig. 8d). In the coldest part of winter, from early February to early March, the simulated value is better than the simulated value in Fig. $8 c$ and agrees well with the observed value $\left(r^{2}=0.755\right.$, $20 N S=0.562)$. This result supports the view that frost promotes a larger and somewhat quicker response of runoff to rainfall than the absence of frost (Shanley and Chalmers, 1999; Stahli et al., 2001). However, the simulation underestimates the observed value after the snowmelt period. Because the hydraulic conductivity, $k_{1}$, increases temporarily in thawing soil, it was set at $k_{1}=5 k=0.1 \mathrm{~m} / \mathrm{s}$, and $\gamma_{1}=0.4$ was calculated by using 25 Eq. (16) (Fig. 8e). This case reproduces better the observed value in the thawing period from early March to late April $\left(r^{2}=0.742, N S=0.534\right)$. Fig. 8 indicates the simulation result with frost/thaw layer and snow model. The depth of $A_{1}$-layer was regarded as the frost/thaw soil layer calculated by the method described in the Sects. 3.3 and 3.4 in each time step. In particular, at the earlier stage of the thawing process, the
HESSD

3, 2101-2144, 2006

Snowmelt runoff micro-topography and phase change

T. Nakayama and M. Watanabe

Title Page

Abstract

Conclusions

Tables

Figures

14

4

Back

Full Screen / Esc

Printer-friendly Version

Interactive Discussion 
soil layer consists of a surface layer with larger porosity (higher conductivity) and a deeper layer with smaller porosity (smaller conductivity). In this way, the NICE-SNOW reproduces excellently the characteristics of the spring flood, in particular, the early thawing process from mid April to mid May $\left(r^{2}=0.811, N S=0.702\right)$. By using the NICE-

5 SNOW including snow layer and frost/thaw soil layer, the simulation of river discharge was conducted at the entire year of 2001 (Fig. 8g). The simulated value reproduces excellently not only at the snow-free periods (Nakayama and Watanabe, 2004) but also at snowmelt periods $\left(r^{2}=772, N S=0.746\right)$.

\section{Discussion and conclusion}

10 The NICE-SNOW could reproduce well the snowmelt runoff process, for example, the observed values of snow depth, frost depth, soil temperature, soil moisture, groundwater level, and river flow discharge by conducting the quantitative assessment of goodness-of-fit and parameter sensitivity. This model developed a multi-layer surfacerunoff submodel including the effect of micro-topography and meteorology, includes the phase change transitions in soil moisture, and also considered the effect of the snow layer and the frost/thaw soil layer on spring snowmelt runoff. We quantified that the mechanism of spring snowmelt runoff is related to changes in soil structure, soil temperature, soil moisture, and groundwater level, which includes the previous qualitative researches that the frozen soil alters the hydraulic character of soil by restricting the infiltration in the coldest part of winter, increasing the pore size after the thawing process in the soil. The NICE-SNOW could explain how the snowmelt causes the greater time-to-peak of runoff than in snow-free period because some part of meltwater flows as an intermediate flow in the partially-thawed hillslope soil layer.

From these results, a conceptual process of the frost/thaw and the relation to 25 snowmelt runoff is constructed (Fig. 9). The snowmelt period can be divided into three periods. The first is the coldest period when precipitation infiltrates the snow layer and the soil is almost frozen. If the soil moisture is high and the soil has a fine-grained tex-

HESSD

$3,2101-2144,2006$

Snowmelt runoff micro-topography and phase change

T. Nakayama and M. Watanabe

Title Page

Abstract Introduction

Conclusions

Tables References Figures

14

4

Back

Close

Full Screen / Esc

Printer-friendly Version

Interactive Discussion 
ture, concrete frost develops, which forms a surface nearly impermeable to runoff and increases overland flow (Stahli et al., 2001). In this period, the infiltration to the ground is seriously reduced by the blocking effect of the soil frost. The second period is the beginning of the thawing process when the frozen soil melts from both the surface and the 5 deeper layers. The temperature is about $0-2^{\circ} \mathrm{C}$, and the ground surface temperature approaches $0^{\circ} \mathrm{C}$. The snow begins to melt, and this meltwater percolates vertically into the macropores and cracks in the soil, increasing the soil moisture (Daniel and Staricka, 2000). The third period begins when the frozen soil thaws completely. Most of the meltwater flows out directly, adding to the surface runoff, causing a rapid decrease in 10 soil moisture in the soil layer. In the thawing process, a phase delay occurs in the river discharge (Shanley and Chalmers, 1999).

In this study, it became clear that the local effect of snow depth and the frost depth disappears in the snowmelt runoff discharge of catchment (Fig. 8g) in the same way as some previous researches (Flerchinger and Saxton, 1989a, b; Boggild et al., 1999; 15 Shanley and Chalmers, 1999; Stahli et al., 2001) though they are very important as water resources of catchment (Figs. 5 and 6). Because freezing and thawing processes influence the amount of runoff discharge during the early spring, the snowmelt flood continues a longer time than that in the typhoon period (Figs. 8). The NICE-SNOW reproduces this phenomenon excellenly because this model in the Eqs. (7-10) calculates correctly that some part of meltwater flows as an intermediate flow in the partiallythawed hillslope soil layer. This is also related to the simulation result that more than half of total soil moisture stays unfrozen at some places even in winter periods (Fig. 7), which indicates that there is a high degree of spatial heterogeneity of frozen ground. Data assimilation of remote-sensing data, such as snow cover in MOD10-ATBD of MODIS data (Hall et al., 2001) and in NOAA-AVHRR/RADARSAT/ERS-SAR/Landsat TM (Swamy and Brivio, 1997; Mitchell and DeWalle, 1998; Schaper et al., 1999; Nagler et al., 2000), and in-situ measurements with the NICE-SNOW is very powerful to improve model-based estimates of the water resources of catchment for practical benefits in near future.
HESSD

$3,2101-2144,2006$

Snowmelt runoff micro-topography and phase change

T. Nakayama and M. Watanabe

Title Page

Abstract

Conclusions

Tables

Figures

14

4

Back

Full Screen / Esc

Printer-friendly Version

Interactive Discussion 
However, the simulated value has a smaller time-to-peak and a larger peak value a little than the observed value from the mid March to the mid April (Figs. 8). Because the NICE-SNOW can reproduce the time lag of snowmelt in the vertical direction, this discrepancy of runoff is due to an imperfectness of the heat-budget and hillslope surface5 runoff submodel of the NICE-SNOW. While the simulation reproduces well the phase changes in the unsaturated layer in winter periods (Fig. 7), the simulated soil temperature overestimates the observed value in winter season (Table 2). The NICE-SNOW simulates only the soil temperature, and it is necessary to include the effect of water temperature in the unsaturated layer on the soil temperature and on the soil moisture.

10 Furthermore, the water volume always flows to the downward directions of hillslope in the model after the snowmelt volumes by the heat-flux model are inputted to the surface runoff model. In reality, some of the water volumes are frozen at night and start to be melted during the daytime in the early spring period when the temperature takes about $0^{\circ} \mathrm{C}$. It is far more likely that preferential flowpaths exist in the partially-thawed 15 hillslope soil layers. This frozen/melted cycle in the surface runoff is not completely included in the NICE-SNOW, and the disagreement between the simulated values and the observed values occurs, which also relates whether the kinematic wave theory for the hillslope hydrology is appropriate given the high degree of spatial heterogeneity of frozen ground. Anyway, these results suggest that the spring runoff process is closely related to changes in the phase change and frost/thaw soil structure. Therefore, it is necessary to evaluate the mechanism of transformation of soil structure and water phase and their interaction, because temperature, snow depth, and soil moisture at initial freezing influence soil frost formation, retention of soil moisture during freezing/thawing, and soil water movement. To reproduce this effect more correctly, it is 25 necessary to conduct more observation in the vertical direction of local area and simulate by including the frozen/melted cycle in the surface runoff with finer mesh resolution in the vertical direction.

The effect of the spring snowmelt runoff on sediment-load influx and nutrient infiltration is very important (Fig. 2) because the spring snowmelt runoff is a significant
HESSD

3, 2101-2144, 2006

Snowmelt runoff micro-topography and phase change

T. Nakayama and M. Watanabe

Title Page

Abstract

Conclusions

Tables

14

4

Back

Full Screen / Esc

Printer-friendly Version

Interactive Discussion 
component of the water balance in the Kushiro River catchment (Fig. 8g) and the soil structure changes dramatically during this period. The drying phenomenon in the Kushiro Mire is closely related with the increased influx of sediments from the surrounding area, where agricultural development, reclamation, and channelization of the 5 river occurred (Talbot and Lapointe, 2002; Nakayama and Watanabe, 2004). In order to stop the sediment-load and nutrient influx and to recover the Kushiro Mire, several ministries in Japan started a new project to re-meander the channelized rivers in 2002 (Ministry of Environment, 2002). The combination of GIS-data such as slope angle, soil properties (Fig. 4 in Nakayama and Watanabe, 2004), and land cover (Fig. 1), with

10 the sediment/nutrient transport model is very powerful in estimating the sediment flux into the mire. The NICE-SNOW can simulate the relation between water and sediment/nutrient influx to the mire in the long-term periods by including the mass-transfer and chemical-reaction processes to this model, which will be very important in protecting the sediment-load and the nutrient influx from riparian forests, and in predicting the 15 recovery of a mire ecosystem by re-meandering the channelized rivers. The extension of the model with the vegetation growth (tree regeneration and succession, etc.) model (Glenn-Lewin et al., 1992), which also includes the clarification of the interaction between the water-heat-sediment-nutrient-vegetation by using the method such as the correspondence analysis, will also be very attractive in order to evaluate the better environmental conditions for the mire, to reproduce the alder invasion to the mire, and to forecast the possibility of the mire-ecosystem recovery in the future.

\section{Appendix A}

\section{Mathematical background}

25 Governing equations for NICE prognostic variables are as follows (Nakayama and Watanabe, 2004):

\section{HESSD}

3, 2101-2144, 2006

Snowmelt runoff micro-topography and phase change

T. Nakayama and M. Watanabe

Title Page

Abstract Introduction

Conclusions

Tables

References Figures

14

4

Back

Close

Full Screen / Esc

Printer-friendly Version

Interactive Discussion 
A1 Biophysical and soil moisture models

(a) Canopy, ground surface, and deep soil temperatures

HESSD

$C_{c} \frac{\partial T_{c}}{\partial t}=R n_{c}-H_{c}-\lambda E_{c}-\xi_{c S}$

$C_{g} \frac{\partial T_{g}}{\partial t}=R n_{g}-H_{g}-\lambda E_{g}-\frac{2 \pi C_{d}}{\tau_{d}}\left(T_{g}-T_{d}\right)-\xi_{g s}$

$C_{d} \frac{\partial T_{d}}{\partial t}=\frac{1}{2 \sqrt{365 \pi}}\left(R n_{g}-H_{g}-\lambda E_{g}\right)$

\section{3, 2101-2144, 2006}

Snowmelt runoff micro-topography and phase change

T. Nakayama and M. Watanabe

where $T_{c}, T_{g}, T_{d}=$ canopy, ground surface, and deep soil temperatures (K); $R n_{c}, R n_{g}$ = absorbed net radiation of canopy and ground $\left(\mathrm{W} / \mathrm{m}^{2}\right) ; H_{C}$ and $H_{g}=$ sensible heat flux $\left(\mathrm{W} / \mathrm{m}^{2}\right) ; E_{c}$ and $E_{g}=$ evapotranspiration rates $\left(\mathrm{kg} / \mathrm{m}^{2} / \mathrm{s}\right) ; C_{c}, C_{g}, C_{d}=$ effective heat capacities $\left(\mathrm{J} / \mathrm{m}^{2} / \mathrm{K}\right) ; \lambda=$ latent heat of vaporization $(\mathrm{J} / \mathrm{kg}) ; \tau_{d}=$ daylength $(\mathrm{s}) ; \xi_{c s}, \xi_{g s}$ = energy transfer due to phase changes in $M_{c}$ and $M_{g}\left(\mathrm{~W} / \mathrm{m}^{2}\right)$.

(b) Interception stores

$\frac{\partial M_{c}}{\partial t}=P-d_{d}-d_{c}-E_{c i} / \rho_{w}$

$\frac{\partial M_{g}}{\partial t}=d_{d}+d_{c}-E_{g i} / \rho_{w}$

Back

Title Page

Abstract

Introduction

Conclusions

References

Tables

Figures

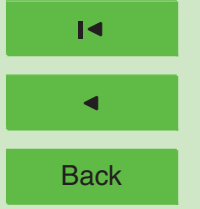

$\rightarrow$

Full Screen / Esc

where $M_{c}, M_{g}=$ thickness of water or snow/ice layer stored on the canopy and on 15 the ground $(\mathrm{m}) ; P=$ precipitation rate $(\mathrm{m} / \mathrm{s}) ; d_{d}=$ canopy throughfall rate $(\mathrm{m} / \mathrm{s})$; $d_{c}=$ canopy drainage rate $(\mathrm{m} / \mathrm{s}) ; E_{c i}, E_{g i}=$ interception loss of canopy and ground

Printer-friendly Version $\left(\mathrm{kg} / \mathrm{m}^{2} / \mathrm{s}\right) ; \mathrm{g} \rho_{w}=$ density of water $\left(\mathrm{kg} / \mathrm{m}^{3}\right)$. 
(c) Soil moisture stores

$\frac{\partial W_{1}}{\partial t}=\frac{1}{\theta_{s} D_{1}}\left[P_{w 1}-q_{1,2}-\frac{1}{\rho_{w}} E_{g s}\right]$

$\frac{\partial W_{2}}{\partial t}=\frac{1}{\theta_{s} D_{2}}\left[q_{1,2}-q_{2,3}-\frac{1}{\rho_{w}} E_{c t}\right]$

$\frac{\partial W_{3}}{\partial t}=\frac{1}{\theta_{s} D_{3}}\left[q_{2,3}-q_{3}\right]$

5 where $W_{i}=$ soil moisture fraction of the i-th layer $\left(=\theta_{i} / \theta_{s}\right) ; \theta_{i}=$ volumetric soil moisture in the i-th layer $\left(\mathrm{m}^{3} / \mathrm{m}^{3}\right) ; \theta_{s}=$ value of $q$ at saturation $\left(\mathrm{m}^{3} / \mathrm{m}^{3}\right) ; D_{i}=$ thickness of the soil layer $(\mathrm{m}) ; q_{i, j}=$ flow between layers $\mathrm{i}$ and $\mathrm{j}(\mathrm{m} / \mathrm{s}) ; q_{3}=$ gravitational drainage from recharge soil moisture store $(\mathrm{m} / \mathrm{s}) ; E_{c t}=$ canopy transpiration $\left(\mathrm{kg} / \mathrm{m}^{2} / \mathrm{s}\right) ; E_{g s}=$ ground evaporation $\left(\mathrm{kg} / \mathrm{m}^{2} / \mathrm{s}\right) ; P_{w 1}=$ infiltration of precipitation into the upper soil moisture 10 store $(\mathrm{m} / \mathrm{s})$.

(d) Canopy conductance to water vapor

$\frac{\partial g_{c}}{\partial t}=-k_{g}\left(g_{c}-g_{c, \text { inf }}\right)$

where $g_{c}=$ canopy conductance $(\mathrm{m} / \mathrm{s}) ; k_{g}=$ time constant $(1 / \mathrm{s}) ; g_{c, i n f}=$ estimated value of $g_{c}$ at $t \rightarrow \infty(\mathrm{m} / \mathrm{s})$.

A2 Groundwater flow model

$\frac{\partial}{\partial x}\left(K_{x x} \frac{\partial h_{a}}{\partial x}\right)+\frac{\partial}{\partial y}\left(K_{y y} \frac{\partial h_{a}}{\partial y}\right)+\frac{\partial}{\partial z}\left(K_{z z} \frac{\partial h_{a}}{\partial z}\right)+F=S_{s} \frac{\partial h_{a}}{\partial t}$

where $K_{x x}, K_{y y}, K_{z z}=$ values of hydraulic conductivity along the $\mathrm{x}, \mathrm{y}$, and $\mathrm{z}$ coordinate axes $(\mathrm{m} / \mathrm{s}) ; x, y=$ horizontal coordinates $(\mathrm{m}) ; z=$ vertical coordinate (positive upwards)

HESSD

$3,2101-2144,2006$

Snowmelt runoff micro-topography and phase change

T. Nakayama and M. Watanabe

Title Page

Abstract

Introduction

Conclusions

References

Tables

Figures

14

4

Back

Close

Full Screen / Esc

Printer-friendly Version

Interactive Discussion

EGU 
$(\mathrm{m}) ; h_{a}=$ aquifer head simulated by the groundwater model $(\mathrm{m}) ; F=$ volumetric flux per unit volume representing sources and/or sinks of water (1/s); $S_{s}=$ specific storage $(1 / \mathrm{m})$.

HESSD

3, 2101-2144, 2006

A3 Surface hydrology model

5 (a) Hillslope hydrology model

$\frac{\partial h_{h}}{\partial t}+\frac{1}{b_{h}(x)} \frac{\partial}{\partial x}\left\{q_{h} b_{h}(x)\right\}=r(x, t) \cos \theta_{h}(x)$

$q_{h}=\operatorname{fracK}_{h} \sin \theta_{h}(x) \gamma h_{h}, \quad\left(0<h_{h}<d_{h}\right)$

$q_{h}=\frac{\sqrt{\sin \theta_{h}(x)}}{n}\left(h_{h}-d_{h}\right)^{m}+\frac{K_{h} \sin \theta_{h}(x)}{\gamma} h_{h}, \quad\left(h_{h} \geq d_{h}\right)$

where $q_{h}=$ hillslope discharge of unit width $\left(\mathrm{m}^{2} / \mathrm{s}\right) ; r(x, t)=$ effective rainfall intensity at position $x$ and time $t(\mathrm{~m} / \mathrm{s}) ; b_{h}(x)=$ width of the flow $(\mathrm{m}) ; \theta_{h}(x)=$ hillslope gradient; $D_{a}=$ thickness of the A-layer $(\mathrm{m}) ; K_{h}=$ hydraulic conductivity in the A-layer $(\mathrm{m} / \mathrm{s}) ; n=$ Manning coefficient (m-s); $m=$ constant value $(=5 / 3) ; H_{a}=$ depth of the rainwater flow in the A-layer $(\mathrm{m}) ; \gamma=$ porosity of the A-layer; $h_{h}=$ apparent flow depth $\left(=g H_{a}\right)(\mathrm{m})$; $d_{h}=$ apparent thickness of the A-layer $\left(=g D_{a}\right)(\mathrm{m})$.

(b) Stream network model

$\frac{\partial A_{r}}{\partial t}+\frac{\partial Q_{r}}{\partial x}=q_{l}$

$\frac{\partial Q_{r}}{\partial t}+\frac{\partial}{\partial x}\left(\frac{Q_{r}^{2}}{A_{r}}\right)+g A_{r} \frac{\partial h_{r}}{\partial x}+g A_{r}\left(I_{f}-i\right)=0$

where $A_{r}=$ cross-sectional area $\left(\mathrm{m}^{2}\right) ; Q_{r}=$ river discharge $\left(\mathrm{m}^{3} / \mathrm{s}\right) ; q_{l}=$ lateral inflow $q$ entering along the side of the river channel simulated by a hillslope model $\left(\mathrm{m}^{2} / \mathrm{s}\right) ; h_{r}$
Snowmelt runoff micro-topography and phase change

T. Nakayama and M. Watanabe

Title Page

Abstract Introduction

Conclusions

References

Tables

Figures

14

4

Back

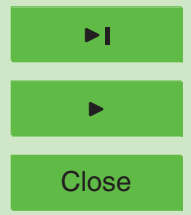

Full Screen / Esc

Printer-friendly Version

Interactive Discussion

EGU 
$=$ flow depth in the river $(\mathrm{m}) ; g=$ gravitational acceleration $\left(\mathrm{m} / \mathrm{s}^{2}\right) ; l_{f}=$ friction slope; $i$ $=$ bed slope.

HESSD

3, 2101-2144, 2006

A4 Integration of models

$q_{f}=-\bar{K} \nabla \Psi=-\bar{K} \frac{\Delta \Psi}{\Delta z}=-\bar{K} \frac{\Psi_{g}-\Psi_{3}}{D_{3} / 2+\left(D_{g}-h_{a}\right)}=\bar{K}\left(\frac{\psi_{3}}{D_{3} / 2+\left(D_{g}-h_{a}\right)}+1\right)$

${ }_{5} r=P-P_{w 1}-\frac{1}{\rho_{w}}\left(E_{c}+E_{g}\right)$

$Q_{s r}=K_{r} A_{b}, \quad\left(h_{a} \leq H_{b}\right)$,

$Q_{s r}=K_{r} \frac{h_{a}-H_{b}}{b_{r}} A_{b}, \quad\left(h_{a}>H_{b}\right)$

where $q_{f}=$ recharge rate in the aquifer $(\mathrm{m} / \mathrm{s}) ; K=$ estimated effective hydraulic conductivity between unsaturated and saturated layers $(\mathrm{m} / \mathrm{s}) ; \Psi_{g}=$ hydraulic potentials at the groundwater level $\left(=h_{a}\right)(\mathrm{m}) ; \Psi_{3}=$ hydraulic potentials at the lowest layer of unsaturated flow $\left(=\psi_{3}+D_{g}+D_{3} / 2\right)(\mathrm{m}) ; D_{g}=$ distance between the top of the second layer and the bottom of the 20th layer in the groundwater model $(\mathrm{m}) ; Q_{s r}=$ volumetric flux of seepage between river and groundwater $\left(\mathrm{m}^{3} / \mathrm{s}\right) ; K_{r}=$ hydraulic conductivity of the riverbed $(\mathrm{m} / \mathrm{s}) ; A_{b}=$ cross-sectional area of the groundwater section $\left(\mathrm{m}^{2}\right) ; b_{r}=$ riverbed thickness $(\mathrm{m}) ; H_{b}=$ hydraulic potential of the river $(\mathrm{m})$.

Acknowledgements. The simulations in this study were conducted on an NEC SX-6 supercomputer at the Center for Global Environment Research (CGER), NIES. Furthermore, the authors wish to thank the Kushiro Development and Construction Department, Hokkaido Regional Development Bureau for providing the observed data of river discharge, nutrient and suspended

\section{Snowmelt runoff -} micro-topography and phase change

T. Nakayama and M. Watanabe

\section{Title Page}

Abstract Introduction

Conclusions

Tables

References

Figures

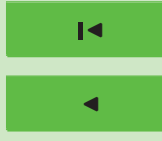

$>1$

Back

Close

Full Screen / Esc

Printer-friendly Version

Interactive Discussion 


\section{References}

Anderson, E. A.: Development and testing of snow pack energy balance equations, Water Resour. Res., 4, 19-37, 1968.

Anderson, E. A.: National Weather Service River Forecast System-snow accumulation and 5 ablation model, NOAA Technical Memorandum NWS HYDRO-17, U.S. Dept. Commerce, Silver Spring, MD, 1973.

Benoit, G. R., Young, R. A., and Lindstrom, M. J.: Freezing induced field soil water changes during five winters I west central Minnesota, Trans. ASAE, 31, 1108-1114, 1988.

Boggild, C. E., Knudby, C. J., Knudsen, M. B., and Starzer, W.: Snowmelt and runoff modeling of an Arctic hydrological basin in west Greenland, Hydrol. Processes, 13, 1989-2002, 1999.

Burnash, R. J. C., Ferral, R. L., and McGuire, R. A.: A generalized streamflow simulation system: Conceptual models for digital computers, Technical Report, Joint Fed.-State River Forecast Cent., U.S. Natl. Weather Serv. and Calif. Dep. of Water Resour., Sacramento, Calif, 1973.

15 Chamberlain, E. J. and Gow, A. J.: Effect of freezing and thawing on the permeability and structure of soils, Eng. Geol., 13, 73-92, 1979.

Cherkauer, K. A. and Lettenmaier, D. P.: Hydrologic effects of frozen soils in the upper Mississippi River basin, J. Geophys. Res., 104, 19599-19610, 1999.

Daniel, J. A. and Staricka, J. A.: Frozen soil impact on ground water-surface water interaction, J. Am. Water Resour. Assoc., 36, 151-160, 2000.

Ek, M. B., Mitchell, K. E., Lin, Y., Rogers, E., Grunmann, P., Koren, V., Gayno, G., and Tarpley, J. D.: Implementation of Noah land surface model advances in the National Centers for Environmental Prediction operational mesoscale Eta model, J. Geophys. Res., 108(D22), 8851, doi:10.1029/2002JD003296, 2003.

25 Flerchinger, G. N. and Saxton, K. E.: Simultaneous heat and water model of a freezing snowresidue-soil system I. Theory and development, Trans. ASAE, 32, 565-571, 1989a.

Flerchinger, G. N. and Saxton, K. E.: Simultaneous heat and water model of a freezing snowresidue-soil system II. Field verification, Trans. ASAE, 32, 573-578, $1989 \mathrm{~b}$.

Ghate, S. R. and Whitely, H. R.: Gawser model user's manual, School of Engineering, University of Guelph, Guelph, Ontario, Canada, Technical Report, 126-137, 1977.

Glenn-Lewin, D. C., Peet, R. K., and Veblen, T. T.: Plant succession; Theory and prediction, Chapman \& Hall, London, 1992.

\section{HESSD}

3, 2101-2144, 2006

Snowmelt runoff micro-topography and phase change

T. Nakayama and M. Watanabe

Title Page

Abstract Introduction

Conclusions

Tables

References

Figures

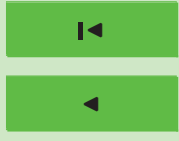

$\rightarrow$ I

Back

Close

Full Screen / Esc

Printer-friendly Version

Interactive Discussion 
Hall, D. K., Riggs, G. A., and Salomonson, V. V.: Algorithm theoretical basis document (ATBD) for the MODIS snow and sea ice-mapping algorithms, version 5.0, 1-45, 2001.

Hartman, M. D., Baron, J. S., Lammers, R. B., Cline, D. W., Band, L. E., Liston, G. E., and Tague, C.: Simulation of snow distribution and hydrology in a mountain basin, Water Resour. 5 Res., 35, 1587-1603, 1999.

Hayhoe, H. N., Pelletier, R. G., and van Vliet, L. J. P.: Estimation of snowmelt runoff in the Peace River region using a soil moisture budget, Can. J. Soil Sci., 73, 489-501, 1993.

Hydrologic Engineering Center (HEC): HEC-RAS river analysis system user's manual (CPD68), Hydrologic Enginnering Center, Davis, Calif., 1997.

10 Ishikawa, M. and Suzuki, T.: Distribution of maximum freezing depths in the ground in the winter of 1964-65 in Hokkaido, Annuals of Hokkaido Forestry Research Institute, 238-248, 1964 (in Japanese).

Johnsson, $\mathrm{H}$. and Lundin, L.-C.: Surface runoff and soil water percolation as affected by snow and soil frost, J. Hydrol., 122, 141-159, 1991.

15 Johnsson, $\mathrm{H}$. and Jansson, P.-E.: Water balance and soil moisture dynamics of field plots with barley and grass ley, J. Hydrol., 129, 149-173, 1991.

Justice, C. O., Vermote, E., Townshend, J. R. G., et al.: The moderate resolution imaging spectroradiometer (MODIS): land remote sensing for global change research, IEEE Trans. Geosci. Remote Sensing, 36, 1228-1249, 1998.

Kennedy, I. and Sharratt, B.: Model comparisons to simulate soil frost depth, Soil Sci., 163, 636-645, 1998.

Koster, R. and Suarez, M.: Energy and water balance calculations in the Mosaic LSM, NASA Tech. Memo., 104606, 9, 60 pp., 1996.

Leavesley, G. H., Lichty, R. W., Troutman, B. M., and Saindou, L.G.: Precipitation-runoff modeling system, user's manual, U.S. Geological Survey Water Resources Investigators Report, B3-4238, 1983.

Liang, X., Lettenmaier, D. P., Wood, E. F., and Burges, S. J.: A simple hydrologically based model of land surface water and energy fluxes for GCMs, J. Geophys. Res., 99, 14415$14428,1994$.

30 Lundin L.-C.: Hydraulic properties in an operational model of frozen soil, J. Hydrol., 118, 289310, 1990.

Mamiya, K. and Chiba, Y.: The behavior of volcanic ash slope with freezing, frost heaving and thawing, Annuals of Applied Geology, 7, 85-102, 1985 (in Japanese).

HESSD

3, 2101-2144, 2006

Snowmelt runoff micro-topography and phase change

T. Nakayama and M. Watanabe

Title Page

Abstract Introduction

Conclusions

Tables

References

Figures

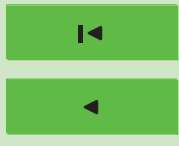

$>1$

Back

Close

Full Screen / Esc

Printer-friendly Version

Interactive Discussion 
Martinec, J. and Rango, A.: Parameter values for snowmelt runoff modeling, J. Hydrol., 84, 197-219, 1986.

Ministry of Environment: Law for the Promotion of Nature Restoration, 148, http://www.env.go. jp/nature/saisei/law-saisei/law_e.pdf, 2002.

5 Mitchell, K. M. and DeWalle, D. R.: Application of the snowmelt runoff model using multipleparameter landscape zones on the Towanda creek basin, Pennsylvania, J. Am. Water Resour. Assoc., 34, 335-346, 1998.

Nagler, T., Rott, H., and Glendinning, G.: Snowmelt runoff modeling by means of RADARSAT and ERS SAR, Can. J. Remote Sensing, 26, 512-520, 2000.

10 Nakayama, T. and Watanabe, M.: Simulation of drying phenomena associated with vegetation change caused by invasion of alder (Alnus japonica) in Kushiro Mire, Water Resour. Res., 40, doi:10.1029/2004WR003174, 2004.

Nash, J. E. and Sutcliffe, J. V.: Riverflow forecasting through conceptual model, J. Hydrol., 10, 282-290, 1970.

Nelson, F. E., Shiklomanov, N. I., Mueller, G. R., et al.: Estimating active-layer thickness over a large region: Kuparuk River Basin, Alaska, USA., Arct. Alp. Res., 29, 367-378, 1997.

Nyberg, L., Stahli, M., Mellander, P.-E., and Bishop, K. H.: Soil frost effects on soil water and runoff dynamics along a boreal transect: 1. Field investigations, Hydrol. Process., 15, 909926, 2001.

Ohara, T., Matsushita, K., Futamase, K., et al.: Explanatory text of the hydrogeological maps of Hokkado - Kushiro, Geological Survey of Hokkaido, 1975.

Pawluk, S.: Freeze-thaw effects on granular structure reorganization for soil materials of varying texture and moisture content, Can. J. Soil Sci., 68, 485-494, 1988.

Schaper, J., Martinec, J., and Seidel, K.: Distributed mapping of snow and glaciers for improved runoff modeling, Hydrol. Process., 13, 2023-2031, 1999.

Schuh, W. M.: Seasonal variation of clogging of an artificial recharge basin in a northern climate, J. Hydrol., 121, 193-215, 1990.

Sellers, P. J., Randall, D. A., Collatz, G. J., Berry, J. A., Field, C. B., Dazlich, D. A., Zhang, C., Collelo, G. D., and Bounoua, L.: A revised land surface prameterization (SiB2) for atomospheric GCMs. Part I : Model formulation, J. Climate, 9, 676-705, 1996.

Semadeni-Davies, A.: Monthly snowmelt modeling for large-scale climate change studies using the degree day approach, Ecol. Model., 101, 303-323, 1997.

Shanley, J. B. and Chalmers, A.: The effect of frozen soil on snowmelt runoff at Sleepers River,

HESSD

3, 2101-2144, 2006

Snowmelt runoff micro-topography and phase change

T. Nakayama and M. Watanabe

Title Page

Abstract Introduction

Conclusions

Tables

References

Figures

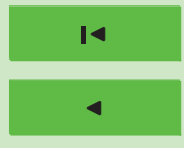

$\rightarrow$ I

Back

Close

Full Screen / Esc

Printer-friendly Version

Interactive Discussion 
Vermont, Hydrol. Process., 13, 1843-1857, 1999.

Sharratt, B., Benoit, G., Daniel, J., and Staricka, J.: Snow cover, frost depth, and soil water across a prairie pothole landscape, Soil Sci., 164, 483-492, 1999.

Stahli, M., Nyberg, L., Mellander, P.-E., Jansson, P.-E., and Bishop, K. H.: Soil frost effects on 5 soil water and runoff dynamics along a boreal transect: 2. Simulations, Hydrol. Process., 15, 927-941, 2001.

Stahli, M., Jansson, P.-E., and Lundin, L.-C.: Soil moisture redistribution and infiltration in frozen sandy soils, Water Resour. Res., 35, 95-103, 1999.

Stahli, M. and Jansson, P.-E.: Test of two SVAT snow submodels during different winter conditions, Agric. Meteorol., 92, 29-41, 1998.

Swamy, A. N. and Brivio, P. A.: Modelling runoff using optical satellite remote sensing data in a high mountainous alpine catchment of Italy, Hydrol. Process., 11, 1475-1491, 1997.

Takasao, T. and Shiiba, M.: Incorporation of the effect of concentration of flow into the kinematic wave equations and its applications to runoff system lumping, J. Hydrol., 102, 301-322, 1980.

Talbot, T. and Lapointe, M.: Modes of response of a gravel bed river to meander straightening: The case of the Sainte-Marguerite River, Saguenay Region, Quebec, Canada, Water Resour. Res., 38, doi:10.1029/2001WR000324, 2002.

The Institute of Geocryology: General Geocryology, Academy of Soviet Union, 1974.
U.S. Army Corps of Engineers: User's manual, SSARR model, streamflow synthesis and reservoir, North Pacific Division, 1991.

\section{HESSD}

3, 2101-2144, 2006

Snowmelt runoff micro-topography and phase change

T. Nakayama and M. Watanabe

Title Page

Abstract Introduction

Conclusions References

Tables

14

4

Back
Figures

$\rightarrow 1$

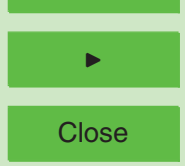

Full Screen / Esc

Printer-friendly Version 
Table 1. Lists of observation and AMeDAS (Automated Meteorological Data Acquisition System) data points. These locations are plotted in Fig. 1.

HESSD

3, 2101-2144, 2006

\begin{tabular}{|c|c|c|c|c|c|}
\hline No. & Point Name & Type & Lat. & Lon. & Elev. $(m)$ \\
\hline$A-1$ & Onnenai (Mire) & Meteorology & $43^{\circ} 06^{\prime} 05^{\prime \prime}$ & $144^{\circ} 20^{\prime} 29^{\prime \prime}$ & 8.00 \\
\hline$A-2$ & Teshikaga (Grassland) & Meteorology & $43^{\circ} 31^{\prime} 08^{\prime \prime}$ & $144^{\circ} 28^{\prime} 10^{\prime \prime}$ & 187.00 \\
\hline$A-3$ & Shibecya (Forest) & Meteorology & $43^{\circ} 20^{\prime} 18^{\prime \prime}$ & $144^{\circ} 38^{\prime} 55^{\prime \prime}$ & 127.00 \\
\hline $\mathrm{M}-1$ & Kawayu & Meteorology & $43^{\circ} 38^{\prime} 18^{\prime \prime}$ & $144^{\circ} 27^{\prime} 24^{\prime \prime}$ & 133.00 \\
\hline$M-2$ & Teshikaga & Meteorology & $43^{\circ} 30^{\prime} 54^{\prime \prime}$ & $144^{\circ} 28^{\prime} 48^{\prime \prime}$ & 198.00 \\
\hline M-3 & Akanko & Meteorology & $43^{\circ} 26^{\prime} 00^{\prime \prime}$ & $144^{\circ} 05^{\prime} 36^{\prime \prime}$ & 430.00 \\
\hline M-4 & Shibecha & Meteorology & $43^{\circ} 18^{\prime} 24^{\prime \prime}$ & $144^{\circ} 36^{\prime} 18^{\prime \prime}$ & 32.00 \\
\hline$M-5$ & Tsurui & Meteorology & $43^{\circ} 13^{\prime} 48^{\prime \prime}$ & $144^{\circ} 19^{\prime} 30^{\prime \prime}$ & 42.00 \\
\hline M-6 & Nakateshibetsu & Meteorology & $43^{\circ} 11^{\prime} 48^{\prime \prime}$ & $144^{\circ} 08^{\prime} 48^{\prime \prime}$ & 80.00 \\
\hline M-7 & Sakakimachi & Meteorology & $43^{\circ} 07^{\prime} 06^{\prime \prime}$ & $145^{\circ} 06^{\prime} 54^{\prime \prime}$ & 2.00 \\
\hline M-8 & Ohta & Meteorology & $43^{\circ} 05^{\prime} 24^{\prime \prime}$ & $144^{\circ} 46^{\prime} 54^{\prime \prime}$ & 85.00 \\
\hline M-9 & Shiranuka & Meteorology & $42^{\circ} 58^{\prime} 06^{\prime \prime}$ & $144^{\circ} 03^{\prime} 54^{\prime \prime}$ & 9.00 \\
\hline$M-10$ & Kushiro & Meteorology & $42^{\circ} 58^{\prime} 30^{\prime \prime}$ & $144^{\circ} 23^{\prime} 30^{\prime \prime}$ & 32.00 \\
\hline$M-11$ & Chippomanai & Meteorology & $42^{\circ} 56^{\prime} 06^{\prime \prime}$ & $144^{\circ} 44^{\prime} 12^{\prime \prime}$ & 145.00 \\
\hline $\mathrm{R}-1$ & Onnenai (Onnenai River) & River Discharge & $43^{\circ} 06^{\prime} 51^{\prime \prime}$ & $144^{\circ} 19^{\prime} 55^{\prime \prime}$ & 6.73 \\
\hline R-2 & Setsuri (Hororo River) & River Discharge & $43^{\circ} 09^{\prime} 17^{\prime \prime}$ & $144^{\circ} 19^{\prime} 48^{\prime \prime}$ & 7.39 \\
\hline $\mathrm{R}-3$ & Otowa (Setsuri River) & River Discharge & $43^{\circ} 11^{\prime} 06^{\prime \prime}$ & $144^{\circ} 20^{\prime} 19^{\prime \prime}$ & 8.80 \\
\hline R-4 & Tsuruhashinai (Tsuruhashinai River) & River Discharge & $43^{\circ} 11^{\prime} 49^{\prime \prime}$ & $144^{\circ} 23^{\prime} 10^{\prime \prime}$ & 15.78 \\
\hline $\mathrm{R}-5$ & Meikyo (Kucyoro River) & River Discharge & $43^{\circ} 09^{\prime} 50^{\prime \prime}$ & $144^{\circ} 27^{\prime} 05^{\prime \prime}$ & 9.85 \\
\hline $\mathrm{R}-6$ & Daini (Kottaro River) & River Discharge & $43^{\circ} 14^{\prime} 20^{\prime \prime}$ & $144^{\circ} 27^{\prime} 52^{\prime \prime}$ & 12.71 \\
\hline R-7 & Numaoro (Numaoro River) & River Discharge & $43^{\circ} 15^{\prime} 40^{\prime \prime}$ & $144^{\circ} 29^{\prime} 53^{\prime \prime}$ & 16.92 \\
\hline $\mathrm{R}-8$ & Shimoosobetsu (Osobetsu River) & River Discharge & $43^{\circ} 16^{\prime} 05^{\prime \prime}$ & $144^{\circ} 32^{\prime} 49^{\prime \prime}$ & 14.04 \\
\hline $\mathrm{R}-9$ & Tohmi (Shirarutoroetoro River) & River Discharge & $43^{\circ} 12^{\prime} 02^{\prime \prime}$ & $144^{\circ} 31^{\prime} 26^{\prime \prime}$ & 7.82 \\
\hline $\mathrm{R}-10$ & Tohro (Arekinai River) & River Discharge & $43^{\circ} 09^{\prime} 11^{\prime \prime}$ & $144^{\circ} 30^{\prime} 18^{\prime \prime}$ & 6.56 \\
\hline $\mathrm{R}-11$ & Isobunnai (Isobunnai River) & River Discharge & $43^{\circ} 23^{\prime} 00^{\prime \prime}$ & $144^{\circ} 32^{\prime} 54^{\prime \prime}$ & 48.44 \\
\hline R-12 & Mansui (Kushiro River) & River Discharge & $43^{\circ} 28^{\prime} 55^{\prime \prime}$ & $144^{\circ} 28^{\prime} 22^{\prime \prime}$ & 91.43 \\
\hline $\mathrm{R}-13$ & Shimotoubetsu (Toubetsu River) & River Discharge & $43^{\circ} 28^{\prime} 49^{\prime \prime}$ & $144^{\circ} 28^{\prime} 12^{\prime \prime}$ & 92.19 \\
\hline
\end{tabular}

Snowmelt runoff micro-topography and phase change

T. Nakayama and M. Watanabe

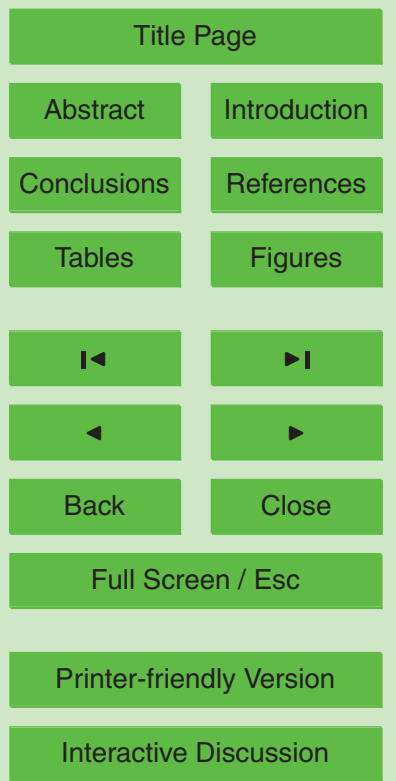


Table 1. Continued.

HESSD

\begin{tabular}{|c|c|c|c|c|c|}
\hline No. & Point Name & Type & Lat. & Lon. & Elev. $(\mathrm{m})$ \\
\hline G-1 & K-1 (Kucyoro River) & Groundwater Level & $43^{\circ} 13^{\prime} 04^{\prime \prime}$ & $144^{\circ} 26^{\prime} 10^{\prime \prime}$ & 18.14 \\
\hline G-2 & K-2 (Kucyoro River) & Groundwater Level & $43^{\circ} 14^{\prime} 53^{\prime \prime}$ & $144^{\circ} 25^{\prime} 19^{\prime \prime}$ & 39.27 \\
\hline G-3 & K-4 (Kucyoro River) & Groundwater Level & $43^{\circ} 16^{\prime} 49^{\prime \prime}$ & $144^{\circ} 22^{\prime} 46^{\prime \prime}$ & 73.48 \\
\hline G-4 & K-7 (Kucyoro River) & Groundwater Level & $43^{\circ} 20^{\prime} 46^{\prime \prime}$ & $144^{\circ} 20^{\prime} 48^{\prime \prime}$ & 139.55 \\
\hline G-5 & K-9 (Kucyoro River) & Groundwater Level & $43^{\circ} 21^{\prime} 56^{\prime \prime}$ & $144^{\circ} 18^{\prime} 07^{\prime \prime}$ & 200.00 \\
\hline G-6 & T-1 (Toubetsu River) & Groundwater Level & $43^{\circ} 28^{\prime} 22^{\prime \prime}$ & $144^{\circ} 27^{\prime} 03^{\prime \prime}$ & 111.23 \\
\hline G-7 & T-2 (Toubetsu River) & Groundwater Level & $43^{\circ} 27^{\prime} 56^{\prime \prime}$ & $144^{\circ} 24^{\prime} 00^{\prime \prime}$ & 142.59 \\
\hline G-8 & T-3 (Toubetsu River) & Groundwater Level & $43^{\circ} 29^{\prime} 18^{\prime \prime}$ & $144^{\circ} 22^{\prime} 35^{\prime \prime}$ & 221.89 \\
\hline G-9 & T-5 (Toubetsu River) & Groundwater Level & $43^{\circ} 26^{\prime} 15^{\prime \prime}$ & $144^{\circ} 20^{\prime} 36^{\prime \prime}$ & 234.00 \\
\hline G-10 & I-1 (Isobunnai River) & Groundwater Level & $43^{\circ} 23^{\prime} 29^{\prime \prime}$ & $144^{\circ} 33^{\prime} 35^{\prime \prime}$ & 63.59 \\
\hline G-11 & I-2 (Isobunnai River) & Groundwater Level & $43^{\circ} 25^{\prime} 48^{\prime \prime}$ & $144^{\circ} 33^{\prime} 56^{\prime \prime}$ & 103.57 \\
\hline G-12 & I-5 (Isobunnai River) & Groundwater Level & $43^{\circ} 28^{\prime} 19^{\prime \prime}$ & $144^{\circ} 36^{\prime} 10^{\prime \prime}$ & 196.62 \\
\hline G-13 & O-1 (Osobetsu River) & Groundwater Level & $43^{\circ} 19^{\prime} 56^{\prime \prime}$ & $144^{\circ} 28^{\prime} 53^{\prime \prime}$ & 51.58 \\
\hline G-14 & O-2 (Osobetsu River) & Groundwater Level & $43^{\circ} 23^{\prime} 50^{\prime \prime}$ & $144^{\circ} 24^{\prime} 59^{\prime \prime}$ & 116.33 \\
\hline G-15 & N-1 (Numaoro River) & Groundwater Level & $43^{\circ} 17^{\prime} 45^{\prime \prime}$ & $144^{\circ} 27^{\prime} 55^{\prime \prime}$ & 49.98 \\
\hline G-16 & Ko-1 (Kottaro River) & Groundwater Level & $43^{\circ} 16^{\prime} 28^{\prime \prime}$ & $144^{\circ} 26^{\prime} 23^{\prime \prime}$ & 47.27 \\
\hline G-17 & Tsu-1 (Setsuri River) & Groundwater Level & $43^{\circ} 15^{\prime} 30^{\prime \prime}$ & $144^{\circ} 19^{\prime} 58^{\prime \prime}$ & 58.48 \\
\hline G-18 & Tsu-2 (Setsuri River) & Groundwater Level & $43^{\circ} 16^{\prime} 36^{\prime \prime}$ & $144^{\circ} 15^{\prime} 42^{\prime \prime}$ & 108.02 \\
\hline G-19 & H-1 (Hororo River) & Groundwater Level & $43^{\circ} 12^{\prime} 44^{\prime \prime}$ & $144^{\circ} 16^{\prime} 09^{\prime \prime}$ & 65.77 \\
\hline G-20 & Ta-1 (Tawa River) & Groundwater Level & $43^{\circ} 22^{\prime} 33^{\prime \prime}$ & $144^{\circ} 37^{\prime} 26^{\prime \prime}$ & 58.37 \\
\hline G-21 & C-1 (Tsuruhashinai River) & Groundwater Level & $43^{\circ} 11^{\prime} 34^{\prime \prime}$ & $144^{\circ} 23^{\prime} 35^{\prime \prime}$ & 20.63 \\
\hline G-22 & Ku-1 (Kushiro River) & Groundwater Level & $43^{\circ} 18^{\prime} 56^{\prime \prime}$ & $144^{\circ} 36^{\prime} 21^{\prime \prime}$ & 30.13 \\
\hline G-23 & Ku-2 (Kushiro River) & Groundwater Level & $43^{\circ} 14^{\prime} 04^{\prime \prime}$ & $144^{\circ} 32^{\prime} 55^{\prime \prime}$ & 18.40 \\
\hline G-24 & Ku-3 (Kushiro River) & Groundwater Level & $43^{\circ} 21^{\prime} 01^{\prime \prime}$ & $144^{\circ} 34^{\prime} 03^{\prime \prime}$ & 39.34 \\
\hline G-25 & W-1 (Kushiro Mire) & Groundwater Level & $43^{\circ} 07^{\prime} 31^{\prime \prime}$ & $144^{\circ} 25^{\prime} 51^{\prime \prime}$ & 73.48 \\
\hline G-26 & W-2 (Kushiro Mire) & Groundwater Level & $43^{\circ} 08^{\prime} 02^{\prime \prime}$ & $144^{\circ} 26^{\prime} 41^{\prime \prime}$ & 3.71 \\
\hline G-27 & W-3 (Kushiro Mire) & Groundwater Level & $43^{\circ} 08^{\prime} 12^{\prime \prime}$ & $144^{\circ} 26^{\prime} 32^{\prime \prime}$ & 3.73 \\
\hline G-28 & W-4 (Kushiro Mire) & Groundwater Level & $43^{\circ} 08^{\prime} 57^{\prime \prime}$ & $144^{\circ} 27^{\prime} 17^{\prime \prime}$ & 5.35 \\
\hline G-29 & W-5 (Kushiro Mire) & Groundwater Level & $43^{\circ} 08^{\prime} 53^{\prime \prime}$ & $144^{\circ} 26^{\prime} 48^{\prime \prime}$ & 8.42 \\
\hline G-30 & A-1 (Akita River) & Groundwater Level & $43^{\circ} 26^{\prime} 45^{\prime \prime}$ & $144^{\circ} 30^{\prime} 23^{\prime \prime}$ & 8.16 \\
\hline
\end{tabular}

3, 2101-2144, 2006

Snowmelt runoff micro-topography and phase change

T. Nakayama and M. Watanabe

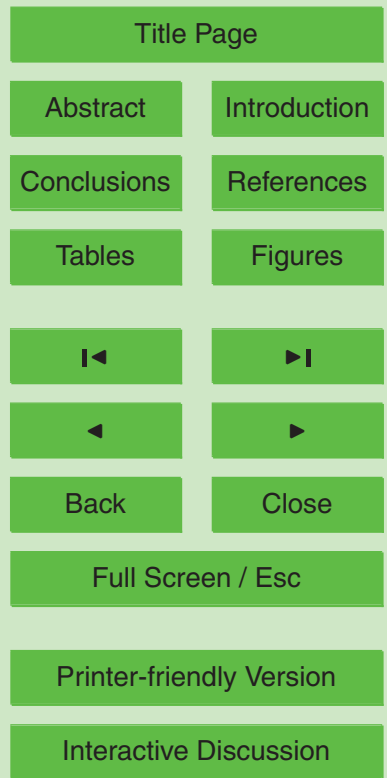


Table 2. Statistical comparison between observed and simulated values about soil temperature and groundwater level.

HESSD

\begin{tabular}{cccccc}
\hline \multicolumn{5}{c}{ Soil temperature } & \multicolumn{5}{c}{ Soil temperature } \\
\hline A-1 & obs.10 cm & cal. $10 \mathrm{~cm}$ & A-1 & obs. $30 \mathrm{~cm}$ & cal. $30 \mathrm{~cm}$ \\
MV & 10.18 & 10.68 & MV & 8.40 & 10.72 \\
SD & 5.55 & 4.54 & SD & 4.49 & 3.55 \\
CV & 0.55 & 0.43 & CV & 0.53 & 0.33 \\
A-2 & obs.10cm & cal. $10 \mathrm{~cm}$ & A-2 & obs. $.30 \mathrm{~cm}$ & cal. $30 \mathrm{~cm}$ \\
MV & 11.92 & 9.54 & MV & 11.64 & 9.77 \\
SD & 5.80 & 5.23 & SD & 4.50 & 3.91 \\
CV & 0.49 & 0.55 & CV & 0.39 & 0.40 \\
A-3 & obs.10cm & cal.10cm & A-3 & obs.30 cm & cal. $30 \mathrm{~cm}$ \\
MV & 10.86 & 10.44 & MV & 10.60 & 10.44 \\
SD & 4.79 & 4.91 & SD & 3.69 & 3.45 \\
CV & 0.44 & 0.47 & CV & 0.35 & 0.33 \\
\hline Groundwater level & & Groundwater level \\
\hline G-1 & obs. & cal. & G-21 & obs. & cal. \\
MV & -0.95 & -0.94 & MV & -3.99 & -4.19 \\
SD & 0.22 & 0.11 & SD & 0.20 & 0.27 \\
CV & -0.23 & -0.12 & CV & -0.05 & -0.06 \\
G-10 & obs. & cal. & G-23 & obs. & cal. \\
MV & -2.83 & -2.45 & MV & -1.59 & -1.40 \\
SD & 0.31 & 0.22 & SD & 0.12 & 0.08 \\
CV & -0.11 & -0.09 & CV & -0.08 & -0.06 \\
G-13 & obs. & cal. & G-29 & obs. & cal. \\
MV & -4.81 & -4.31 & MV & -0.17 & -0.24 \\
SD & 0.30 & 0.13 & SD & 0.05 & 0.11 \\
CV & -0.06 & -0.03 & CV & -0.30 & -0.45 \\
\hline
\end{tabular}

3, 2101-2144, 2006

Snowmelt runoff micro-topography and phase change

T. Nakayama and M. Watanabe

Title Page

Abstract

Introduction

Conclusions

References

Tables

Figures

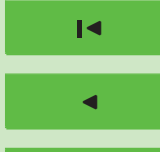

$\rightarrow$

Back

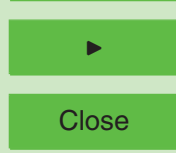

Full Screen / Esc

Printer-friendly Version

Interactive Discussion

$\mathrm{MV}=$ Mean Value, $\mathrm{SD}=$ Standard Deviation

$\mathrm{CV}=$ Coefficient of Variation $(=\mathrm{SD} / \mathrm{MV})$ 


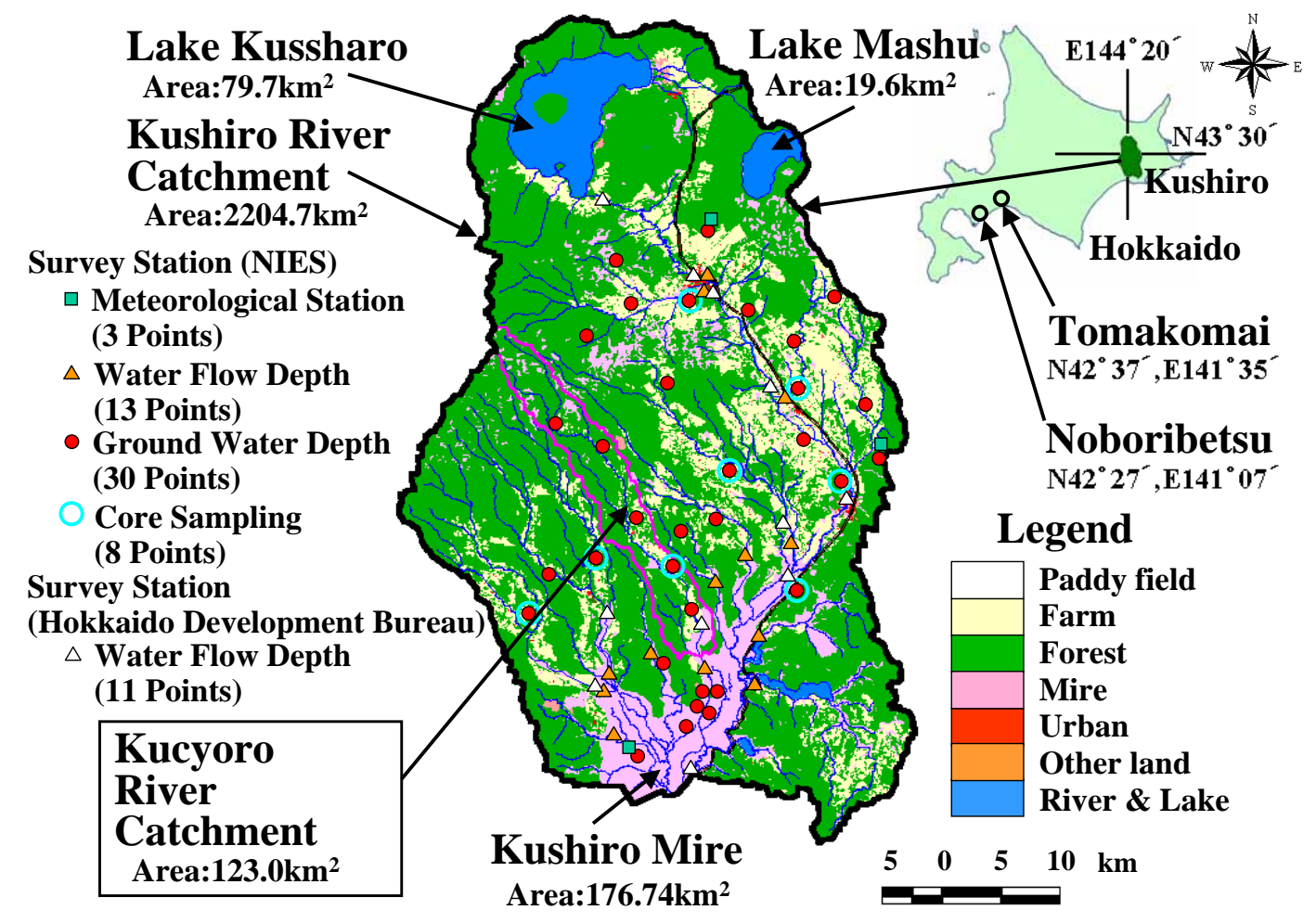

Fig. 1. Land cover and observation points of study area in this research (Kushiro River catchment). Red line is border of study area for snowmelt runoff simulation at Kucyoro River catchment, a tributary of the Kushiro River.

\section{$3,2101-2144,2006$}

Snowmelt runoff micro-topography and phase change

T. Nakayama and M. Watanabe

\section{Title Page}

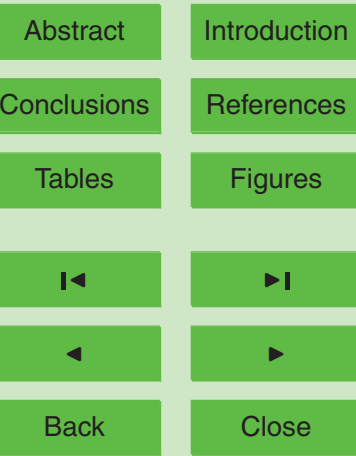

Full Screen / Esc

Printer-friendly Version

Interactive Discussion 


\section{HESSD}
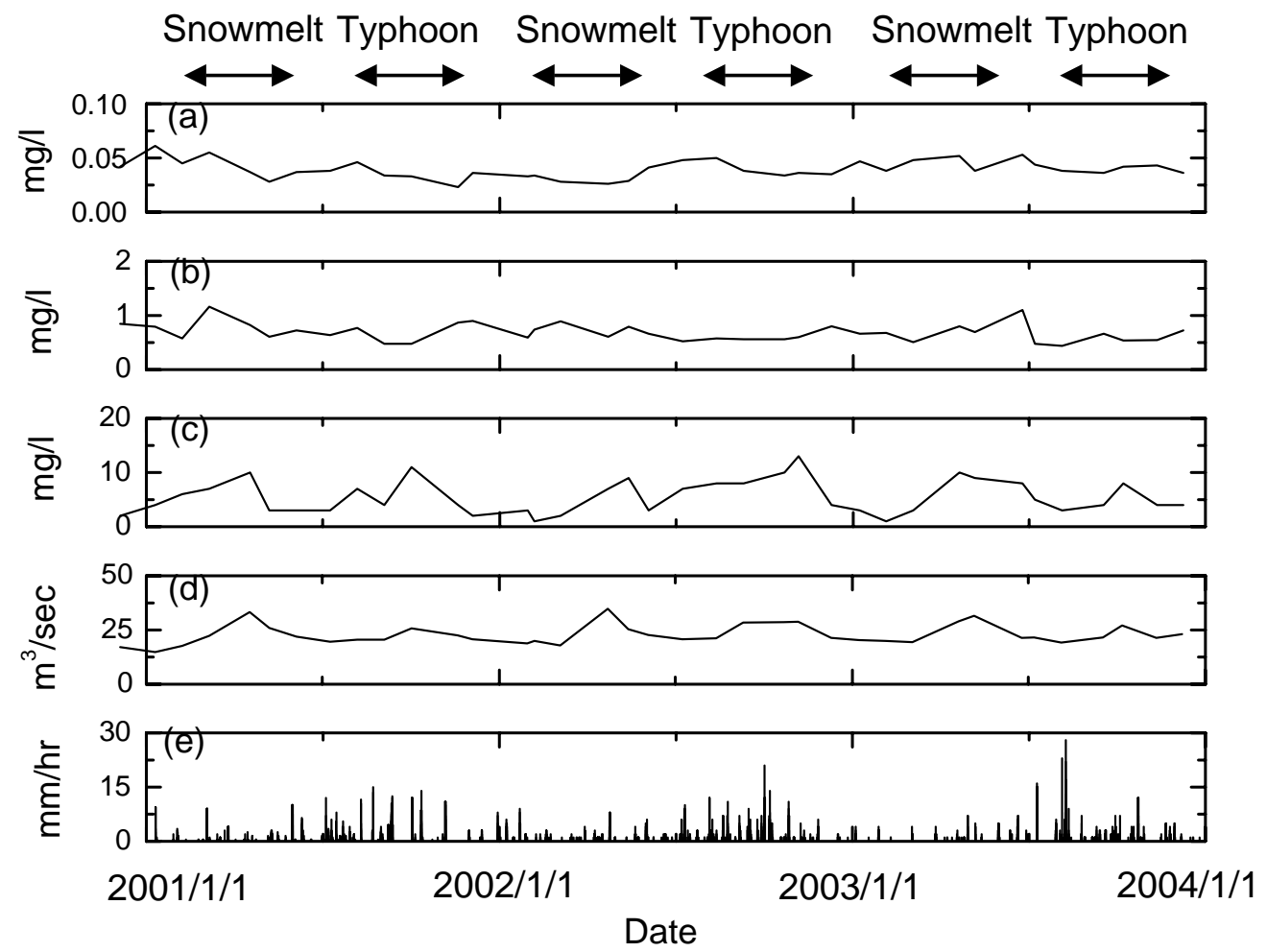

Fig. 2. Observation data of (a) total phosphorus, (b) total nitrogen, (c) suspended load, (d) river discharge (Shibecya observation point; Hokkaido Regional Development Bureau) and (e) precipitation (M-4 in Table 1) (Japan Meteorological Business Support Center) around the Kushiro Mire during 2001-2003.
3, 2101-2144, 2006

Snowmelt runoff micro-topography and phase change

T. Nakayama and M. Watanabe

Title Page

Abstract

Introduction

Conclusions

References

Tables

Figures

14

4

Back

Full Screen / Esc

Printer-friendly Version

Interactive Discussion 


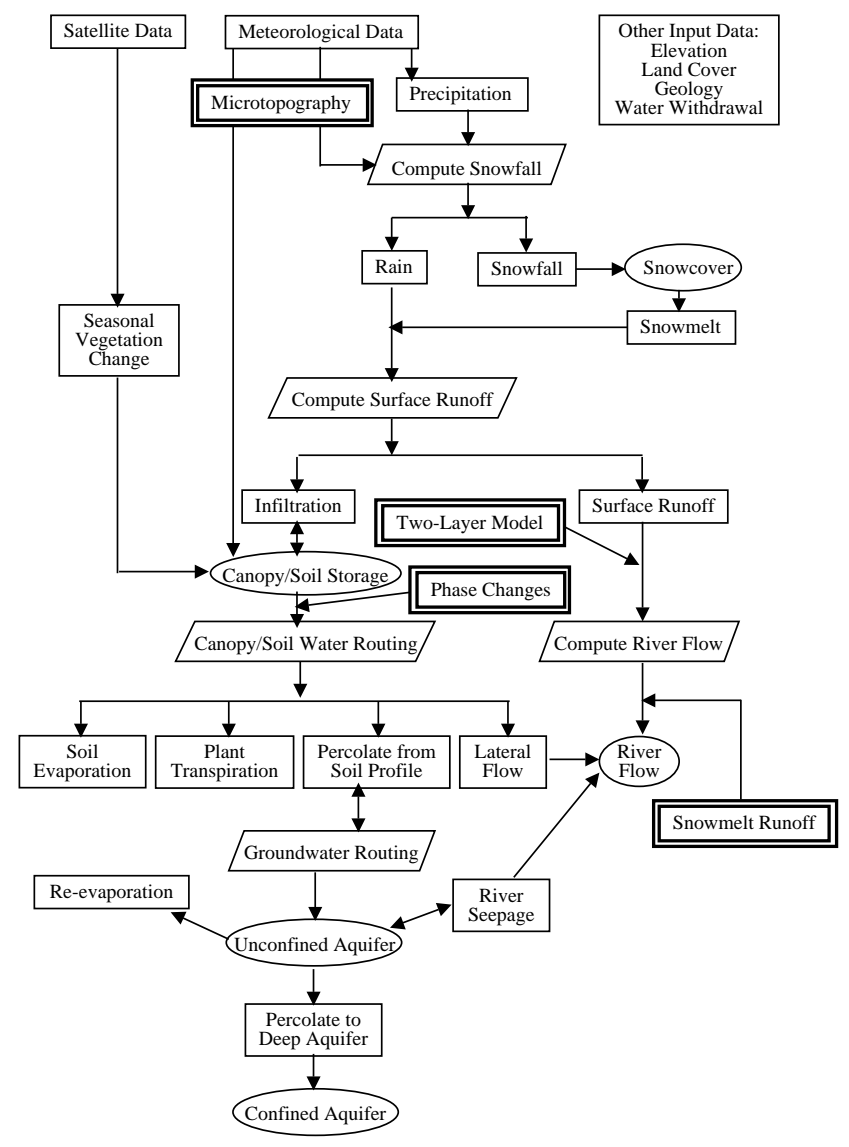

Fig. 3. Flow diagram of NICE-SNOW model. Bold frames indicate the new developed processes in the NICE-SNOW model.

\section{HESSD}

3, 2101-2144, 2006

\section{Snowmelt runoff -} micro-topography and phase change

T. Nakayama and M. Watanabe

Title Page

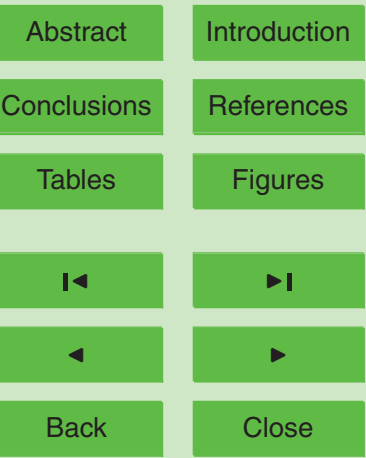

Full Screen / Esc

Printer-friendly Version

Interactive Discussion 
(a)

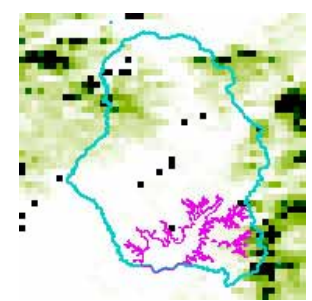

2001/01/25

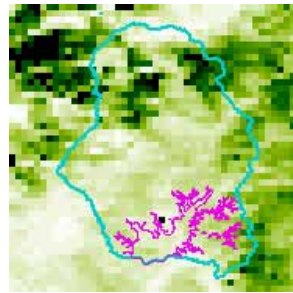

2001/04/15

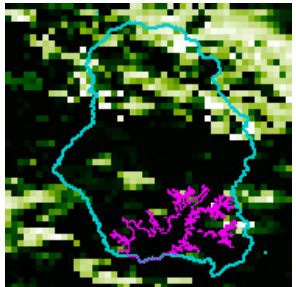

2001/07/04

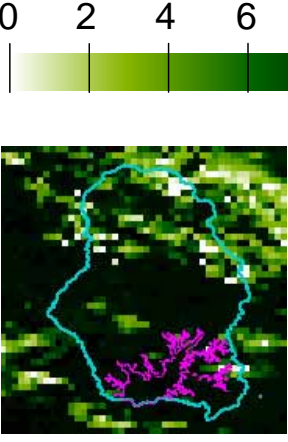

2001/07/04

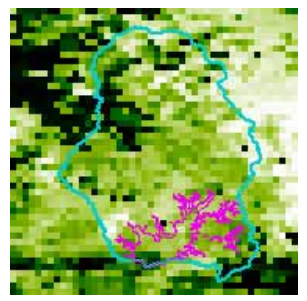

2001/10/08

10

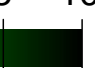

(b)

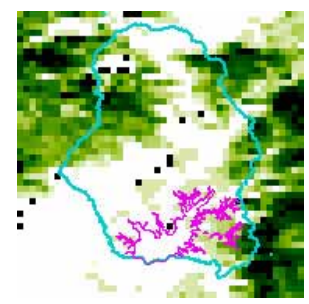

$2001 / 01 / 25$

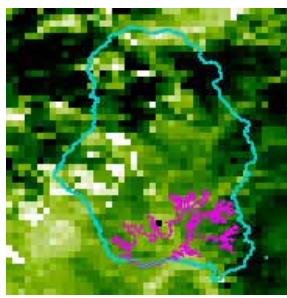

2001/04/15
HESSD

3, 2101-2144, 2006

Snowmelt runoff micro-topography and phase change

T. Nakayama and M. Watanabe

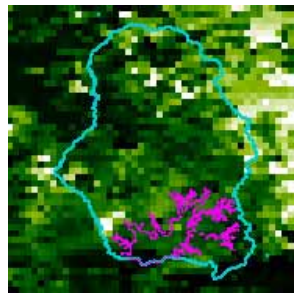

2001/10/08

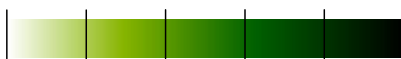

$\begin{array}{llllll}0.0 & 0.2 & 0.4 & 0.6 & 0.8 & 1.0\end{array}\left(\mu \mathrm{mol} / \mathrm{m}^{2} / \mathrm{s}\right)$

Fig. 4. Seasonal variation in MODIS LAI and FPAR images at $1 \mathrm{~km}$ mesh in 2001 (image areas: $43^{\circ} 00^{\prime} \mathrm{N}-43^{\circ} 45^{\prime} \mathrm{N}, 144^{\circ} 00^{\prime} \mathrm{E}-144^{\circ} 45^{\prime} \mathrm{E}$ ), (a) LAI-Image from MODIS-Data, (b) FPARImage from MODIS-Data. Blue line is border of catchment, and pink line is that of Kushiro Mire.
Title Page

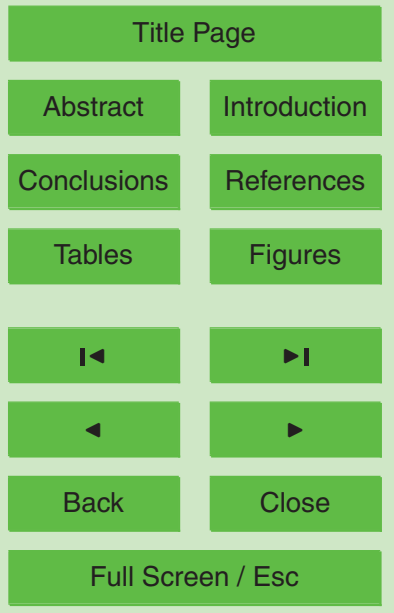

Printer-friendly Version

Interactive Discussion 
(a)

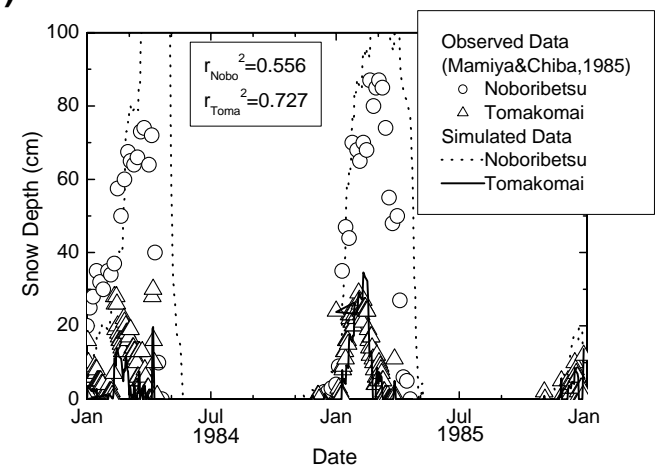

HESSD

3, 2101-2144, 2006

Snowmelt runoff micro-topography and phase change

T. Nakayama and M. Watanabe

(b)

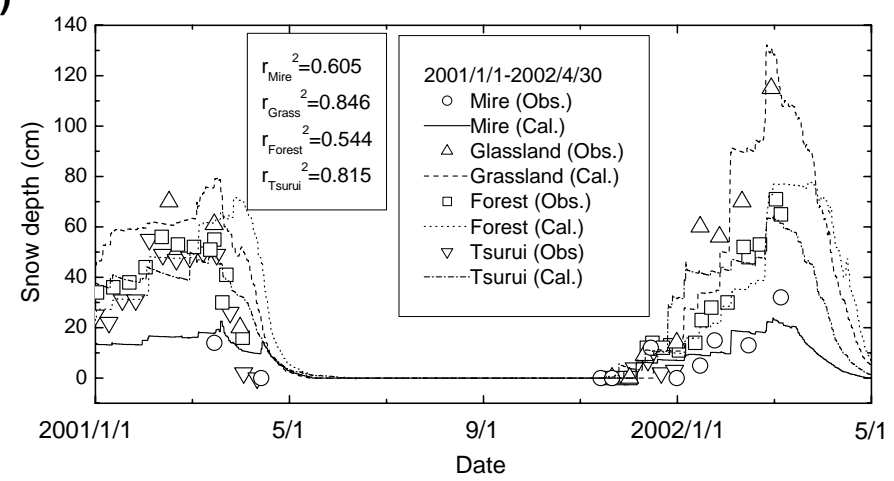

Title Page

Abstract Introduction

Conclusions

References

Tables

Figures

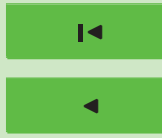

- I

Back

Close

Full Screen / Esc 31 December 1985). Open circle and triangle: observed data (Mamiya and Chiba, 1985); lines and dotted lines: simulated values; and (b) effect of land cover (from 1 January 2001 to 30 April 2002). Open circle, triangle, square, and reverse triangle: observed values at mire (A-1), grassland (A-2), forest (A-3), and Tsurui (M-5) observation point; line, dashed line, dotted line, and dash-dotted line: simulated values. The $r^{2}$ shows the correlation between observed value and simulated value when the slope of regression line equals to 1 . 


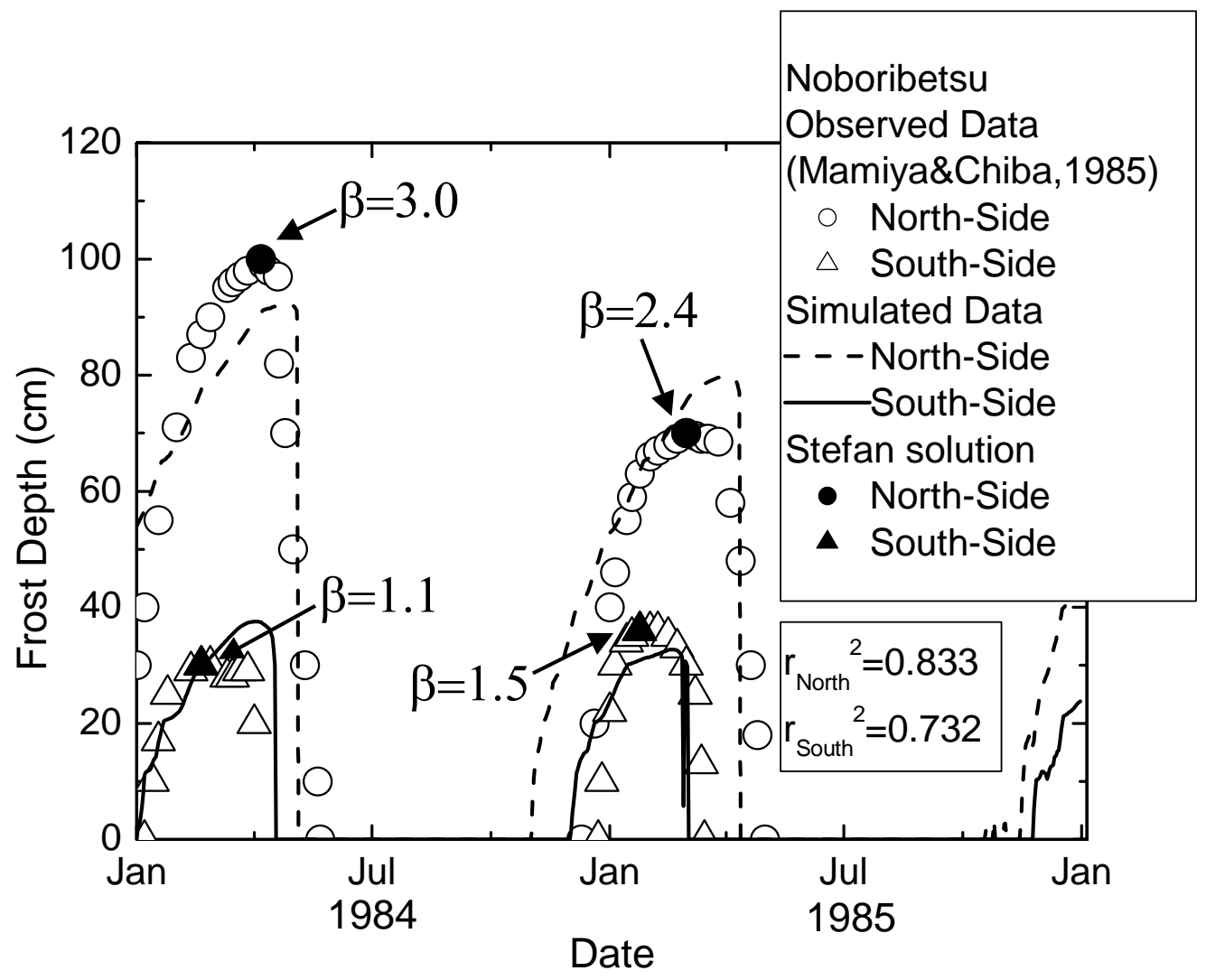

Fig. 6. Comparison of frost depth from 1 January 1984 to 31 December 1985. $\beta$ means the coefficient of the original Stefan solution in the Eq. (11). Open circle and triangle: observed data (Mamiya and Chiba, 1985); lines and dotted lines: simulated values by NICE-2; filled circle and triangle: calculated values by Stefan solution. The $r^{2}$ shows the correlation between observed value and simulated value.
HESSD

3, 2101-2144, 2006

Snowmelt runoff micro-topography and phase change

T. Nakayama and M. Watanabe

Title Page
Abstract

Conclusions

Tables

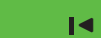

4

Back
Introduction

References

Figures

$\rightarrow$

Close

\section{Full Screen / Esc}

Printer-friendly Version

Interactive Discussion 
(a)

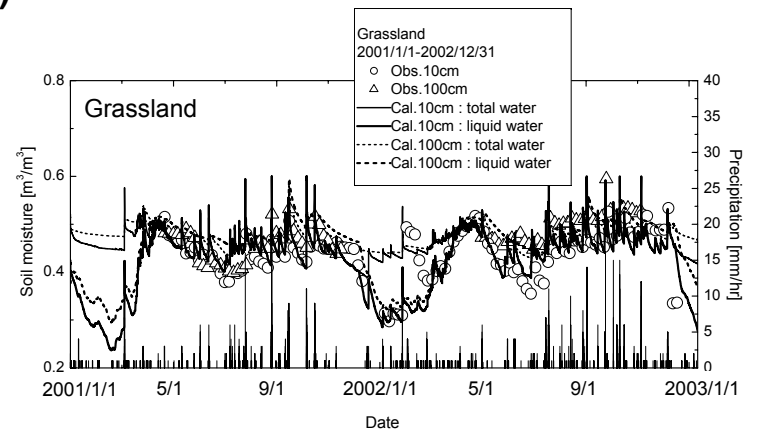

(b)

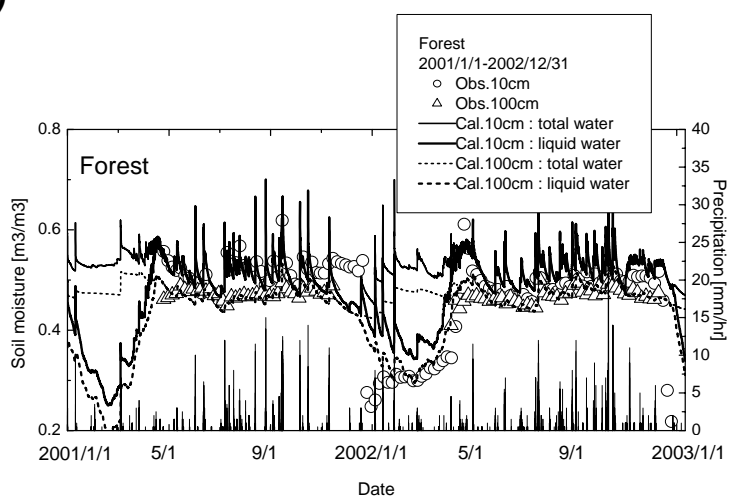

Fig. 7. Time-series of precipitation and soil moisture at two meteorological stations from 1 January 2001 to 31 December 2002 for two years (A-2 and -3 in Table 1). Soil moisture at (a) grassland, and (b) forest, respectively. Open circle and open triangle show observed values at soil depths of $10 \mathrm{~cm}$ and $1.0 \mathrm{~m}$, respectively. Solid line and dashed line show calculated total moisture (ice + liquid) at soil depths of $10 \mathrm{~cm}$ and $1.0 \mathrm{~m}$, respectively. Bold line and bold dashed-line show calculated liquid moisture at soil depths of $10 \mathrm{~cm}$ and $1.0 \mathrm{~m}$, respectively.

\section{HESSD}

3, 2101-2144, 2006

Snowmelt runoff micro-topography and phase change

T. Nakayama and M. Watanabe

Title Page

Abstract

Introduction

Conclusions

References

Tables

Figures

14

$>$ I

$\triangleleft$

Back

Close

Full Screen / Esc

Printer-friendly Version

Interactive Discussion 


\section{HESSD}

을
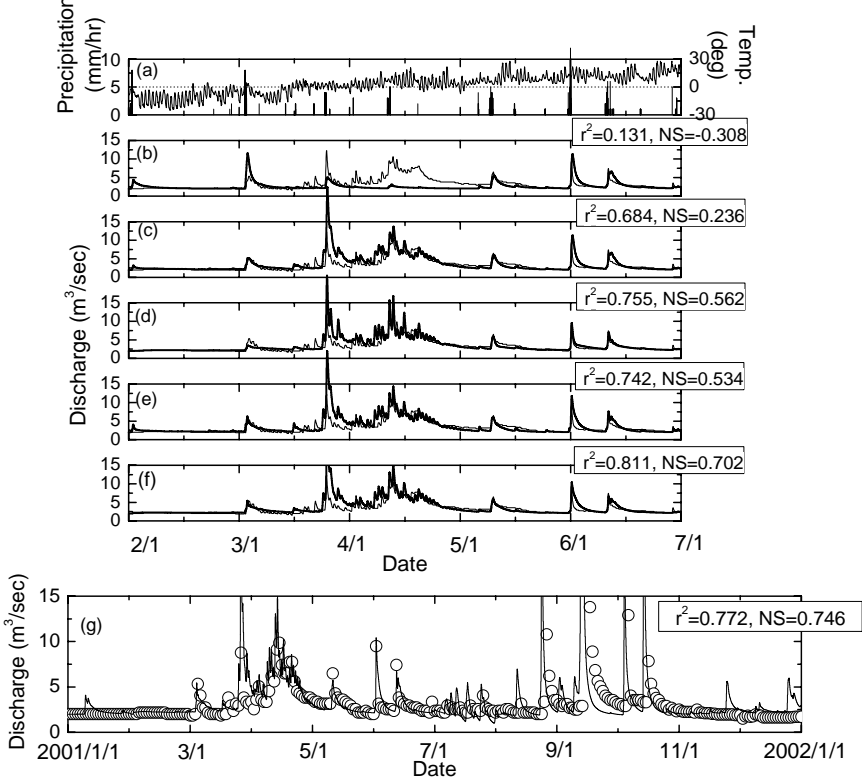

Fig. 8. Time-series of precipitation, temperature, and river discharge at Kushiro River catchment (Shimo-Kucyoro observation point; R-5 in Table 1); (a) precipitation and temperature; river discharge (b) without snow depth and frost depth, (c) with snow model, (d) soil layer is completely frozen with snow model, (e) soil layer is completely thawed with snow model, (f) twolayer model of frost/thaw layer with snow model; $(\mathbf{g})$ river discharge in case-f from 1 January to 31 December 2001. In Figs. 8b-f, line and bold-line show observed and simulated values. In Fig. 8g, open-circles are observed values and lines are simulated values. The $r^{2}$ shows the correlation between observed value and simulated value when the slope of regression line equals to 1, and NS shows Nash-Sutcliffe Criterion NS (Nash and Sutcliffe, 1970).
3, 2101-2144, 2006

Snowmelt runoff micro-topography and phase change

T. Nakayama and M. Watanabe

Title Page

Abstract Introduction

Conclusions

References

Tables

Figures

14

4

Back

Close

Full Screen / Esc

Printer-friendly Version

Interactive Discussion 


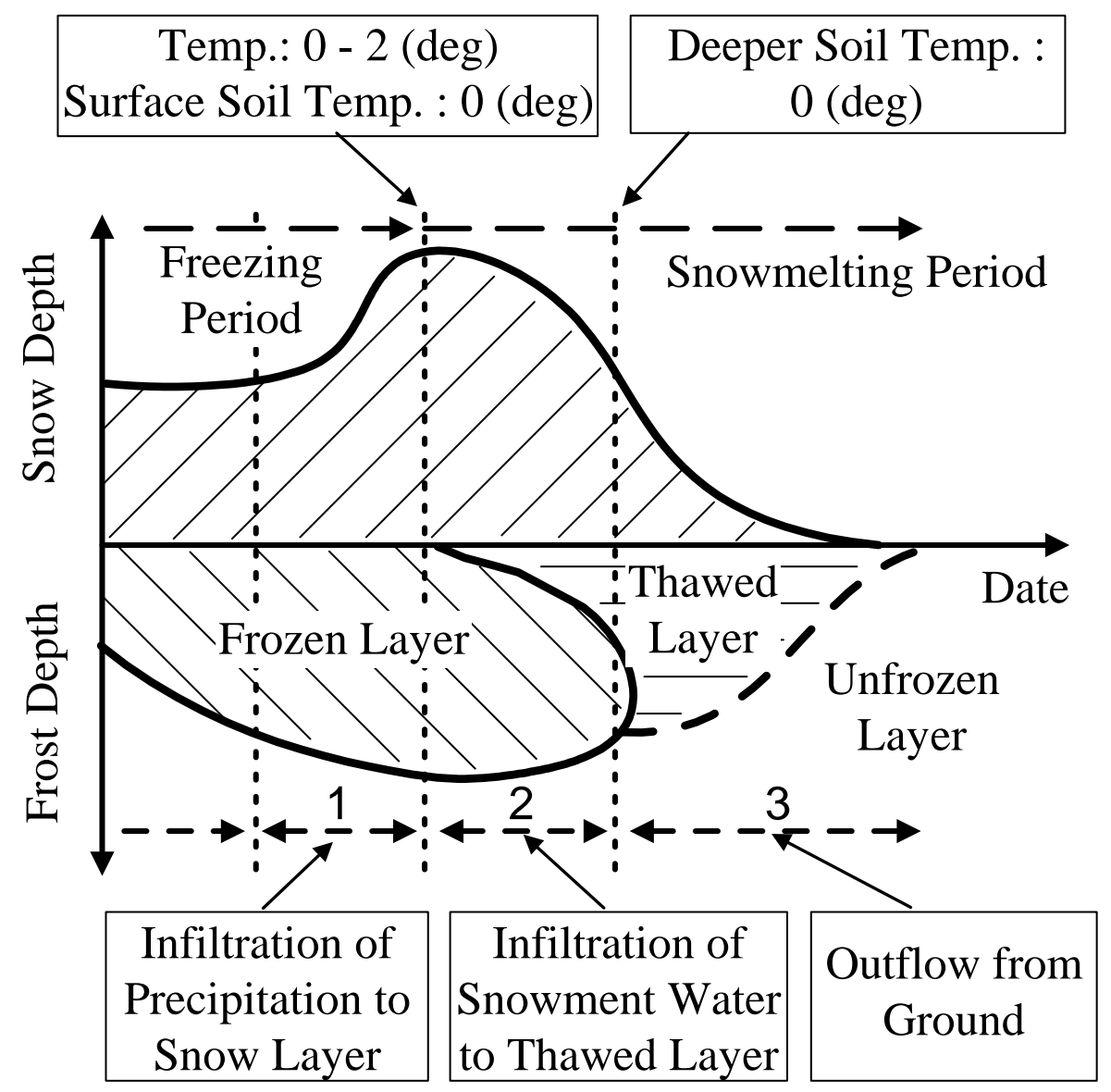

HESSD

3, 2101-2144, 2006

Snowmelt runoff micro-topography and phase change

T. Nakayama and M. Watanabe

Title Page

Abstract

Introduction

Conclusions

References

Tables

Figures

14

$>$ I

4

Back

Close

Full Screen / Esc

Printer-friendly Version

Interactive Discussion

EGU 